\title{
Myeloperoxidase Inhibitory and Antioxidant Activities of (E)-2-Hydroxy- $\alpha$-aminocinnamic Acids Obtained through Microwave-Assisted Synthesis
}

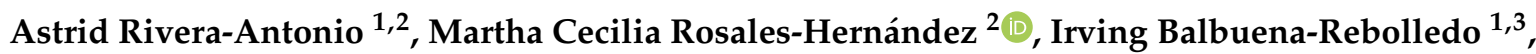 \\ José Martín Santiago-Quintana ${ }^{1,2}{ }^{(}$, Jessica Elena Mendieta-Wejebe ${ }^{2} \mathbb{D}$, José Correa-Basurto ${ }^{3}{ }^{\circ}$, \\ Juan Benjamín García-Vázquez ${ }^{3}$ (D) Efrén Venancio García-Báez ${ }^{1}$ and Itzia I. Padilla-Martínez ${ }^{1, *(1)}$
}

1 Laboratorio de Química Supramolecular y Nanociencias, Unidad Profesional Interdisciplinaria de Biotecnología, Instituto Politécnico Nacional, Avenida Acueducto s/n, Barrio la Laguna Ticomán, Ciudad de México 07340, Mexico; astridmriveraa@gmail.com (A.R.-A.); irving.balbu@gmail.com (I.B.-R.); martinsnqn3@gmail.com (J.M.S.-Q.); efren1003@yahoo.com.mx (E.V.G.-B.)

2 Laboratorio de Biofísica y Biocatálisis, Sección de Estudios de Posgrado e Investigación, Escuela Superior de Medicina, Instituto Politécnico Nacional, Plan de San Luis y Salvador Díaz Mirón s/n, Casco de Santo Tomas, Ciudad de México 11340, Mexico; marcrh2002@yahoo.com.mx (M.C.R.-H.); jesmenwej@yahoo.com (J.E.M.-W.)

check for updates

Citation: Rivera-Antonio, A.; Rosales-Hernández, M.C.; BalbuenaRebolledo, I.; Santiago-Quintana, J.M.; Mendieta-Wejebe, J.E.; CorreaBasurto, J.; García-Vázquez, J.B.; García-Báez, E.V.; Padilla-Martínez, I.I. Myeloperoxidase Inhibitory and Antioxidant Activities of (E)-2Hydroxy- $\alpha$-aminocinnamic Acids Obtained through MicrowaveAssisted Synthesis. Pharmaceuticals 2021, 14, 513. https://doi.org/ $10.3390 /$ ph14060513

Academic Editor: Thierry Besson

Received: 13 April 2021

Accepted: 11 May 2021

Published: 27 May 2021

Publisher's Note: MDPI stays neutral with regard to jurisdictional claims in published maps and institutional affiliations.

Copyright: (c) 2021 by the authors. Licensee MDPI, Basel, Switzerland. This article is an open access article distributed under the terms and conditions of the Creative Commons Attribution (CC BY) license (https:// creativecommons.org/licenses/by/ $4.0 /)$.
3 Laboratorio de Diseño y Desarrollo de Nuevos Fármacos e Innovación Biotecnológica, Escuela Superior de Medicina, Instituto Politécnico Nacional, Plan de San Luis y Díaz Mirón s/n, Col. Casco de Santo Tomas, Ciudad de México 11340, Mexico; corrjose@gmail.com (J.C.-B.); benjagv_5202@hotmail.com (J.B.G.-V.)

* Correspondence: ipadillamar@ipn.mx

Abstract: Myeloperoxidase (MPO) is an enzyme present in human neutrophils, whose main role is to provide defenses against invading pathogens. However, highly reactive oxygen species (ROS), such as $\mathrm{HOCl}$, are generated from MPO activity, leading to chronic diseases. Herein, we report the microwave-assisted synthesis of a new series of stable (E)-(2-hydroxy)- $\alpha$-aminocinnamic acids, in good yields, which are structurally analogous to the natural products $(Z)$-2-hydroxycinnamic acids. The radical scavenging activity (RSA), MPO inhibitory activity and cytotoxicity of the reported compounds were evaluated. The hydroxy derivatives showed the most potent RSA, reducing the presence of DPPH and ABTS radicals by $77 \%$ at $0.32 \mathrm{mM}$ and $100 \%$ at $0.04 \mathrm{mM}$, respectively. Their mechanism of action was modeled with $\mathrm{BDE}_{\mathrm{OH}}$, IP and $\Delta \mathrm{E}_{\mathrm{H}-\mathrm{L}}$ theoretical calculations at the B3LYP/6 $-31+\mathrm{G}(\mathrm{d}, \mathrm{p})$ level. Compounds showed in vitro inhibitory activity of MPO with $\mathrm{IC}_{50}$ values comparable to indomethacin and 5-ASA, but cytotoxicities below 15\% at 100-200 $\mu \mathrm{M}$. Docking calculations revealed that they reach the amino acid residues present in the distal cavity of the MPO active site, where both the amino and carboxylic acid groups of the $\alpha$-aminopropenoic acid arm are structural requirements for anchoring. (E)-2-hydroxy- $\alpha$-aminocinnamic acids have been synthesized for the first time with a reliable method and their antioxidant properties demonstrated.

Keywords: (Z)-2-hydroxycinnamic acid; (E)-dehydro-Phe; hypochlorous acid; antioxidants; 3acetamidocoumarins; 3-aminocoumarins

\section{Introduction}

Myeloperoxidase (MPO) is a hemeprotein member of the peroxidase family that can be found in the azurophil granules of polymorphonuclear neutrophils. The crucial role of MPO in the antimicrobial activity of neutrophils relies on the production of hypochlorous acid $(\mathrm{HOCl})[1]$. This strong oxidant species is able to cross the cell membrane, promoting not only chlorination of lipids, nucleic acids and carbohydrates but also the deamination of amino acids $[2,3]$, which are strongly associated with chronic degenerative diseases such as atherosclerosis [2,4], cancer [5], Alzheimer's, Parkinson's [6] and rheumatoid arthritis [1].

The design of new MPO inhibitors has been based on their diverse modes of action such as complex II accumulation, suicide substrates and reversible union to the native 
enzyme. There are some MPO inhibitors, such as 5-aminosalicylic acid (5-ASA) [7], dapsone, tryptamines and indomethacin, which are considered as inhibitors that cause the accumulation of complex II (peroxidase deficient) [8,9]. Therefore, in order to promote complex II accumulation, these types of inhibitors first react with complex I; the latter being more reactive than the former with two and one oxidation equivalents, respectively, compared to the native MPO [10]. In contrast, suicide substrates such as 4-aminobenzoic acid hydrazide (4-ABAH), benzoic acid hydrazide (BAH) and 2-thioxanthins can be categorized as irreversible inhibitors, which either destroy or modify the covalent bond of the heme group present in the MPO [11]. On the other hand, reversible inhibitors such as salicylhydroxamic acid (SHA) and aromatic hydroxamates compete with the substrate for the active site of the enzyme but without modifying it.

Chronic degenerative diseases have long been associated with oxidative stress, mainly derived from the enzymatic production of reactive oxygen species (ROS) [12,13]. Generally, synthetic molecules designed to counteract the free radical effects are derived from compounds of natural origin and some are structurally similar. Polyphenols constitute a class of antioxidants which are found in the daily diet, commonly known as phytochemicals, where hydroxycinnamic acids are found. Caffeic, ferulic and isoferulic acids are synthesized within some plants such as coffee, cinnamon, citrus fruits and grapes, among others [14]; they are also found in wines [15]. Some of the reported pharmacological properties of cinnamic acid and its derivatives have anti-inflammatory, antimicrobial, antimalarial [16], antidepressant [17], anticancer and antioxidant activities, as well as neuroprotective effects [18].

The antioxidant properties of both cinnamic acid and its hydroxy derivatives can be explained in terms of two important structural features: the presence of a phenol moiety and the propenoic acid on the side chain. Both mentioned moieties have been shown to confer an improved electron delocalization of the backbone upon reaction with free radicals, thus avoiding the stage of radical propagation during the oxidation process [19]. The carboxylic acid functional group and the phenolic ring, in hydroxycinnamic acids, can be found in opposite positions or in the same plane around the double bond. In the first case, cinnamic acids are referred to as $E$ and in the second case as $Z$ isomers, Figure 1 . 2-Hydroxycinnamic acids are a group of compounds of natural origin, very abundant in some foods and appreciated for their antioxidant properties which can be mainly found in the $E$ configuration, whereas the $Z$ configuration is scarce. As a natural product, $(Z)-2-$ hydroxycinnamic acid has been isolated in very small quantities [20,21]. Recent studies in lung cancer showed that $(Z)$-cinnamic acid prevents metastasis to a greater extent than the $(E)$-cinnamic acid [22]. It is worth mentioning that the $(E)$ isomers are more abundant in nature, presumably because they are more stable than the $(Z)$ isomers [23]. There are reported methods for the synthesis of (Z)-2-hydroxycinnamic acids, but the yields are low, at $5-10 \%$, and purification by chromatography is necessary, with the main product being coumarin [24].

Nowadays, the pharmaceutical industry has integrated green chemistry into its processes to obtain products free of solvents and heavy metals [25]. One of the modern green methodologies is microwave-assisted chemical synthesis, which uses the property of polar molecules to transform electromagnetic energy into heat to save time and energy, generating fewer by-products and therefore improving yields, compared to conventional methods [26].

Herein, we present the synthesis of a family of (E)-2-hydroxy- $\alpha$-aminocinnamic acid derivatives obtained through microwave-assisted chemical synthesis in good yields, Figure 1. These compounds are analogous to dehydro-amino acids which are highly valuable synthetic precursors [27] and particularly to $(E)$-dehydro-phenylalanine whose $(Z)$ isomer has recently been used as hydrogelator [28]. In this work, the title compounds have been envisaged as antioxidants due to their structural analogy with (Z)2-hydroxycinnamic acid. The structures of the abovementioned compounds and that of contrasting/inhibitory compounds used in the assays are depicted in Figure 1. Their an- 
tioxidant capabilities were evaluated using the 2,2-diphenyl-1-picrylhydrazyl (DPPH) and 2,2-azino-bis(3-ethylbenzothiazolin)-6-sulfonic acid (ABTS) methods, as long as molecular orbital calculations at the B3LYP /6-31 + G(d,p) level of theory allowed us to rationalize their mechanism of action. Selected compounds exhibited in vitro inhibitory activity against MPO whose interaction in the binding site was modeled by docking calculations. Finally, the cytotoxicity of this set of compounds was evaluated in a 3-(4,5-dimethylthiazol2-yl)-2,5-diphenyltetrazolium bromide (MTT) assay.<smiles>O=C(O)/C=C/c1ccccc1O</smiles>

(E)-2-hydroxycinnamic acid<smiles>O=C(O)/C=C\c1ccccc1O</smiles>

(Z)-2-hydroxycinnamic acid<smiles>N/C(=C/c1ccccc1O)C(=O)O</smiles>

(E)-2-hydroxy- $\alpha$-aminocinnamic acid<smiles>N/C(=C/c1ccccc1)C(=O)O</smiles>

(E)-dehydro-phenylalanine<smiles>N/C(=C\c1ccccc1)C(=O)O</smiles>

(Z)-dehydro-phenylalanine<smiles>Nc1ccc(O)c(C(=O)O)c1</smiles>

5-ASA<smiles>COc1ccc2c(c1)c(CC(=O)O)c(C)n2C(=O)c1ccc(Cl)cc1</smiles>

Indomethacin<smiles>NNC(=O)c1ccc(N)cc1</smiles>

4-ABAH

Figure 1. Structures of $(E)$ - and (Z)-2-hydroxycinnamic acids, (E)-2-hydroxy- $\alpha$-aminocinnamic acid, $(E)$ - and $(Z)$-dehydrophenylalanine, 5-aminosalicylic acid (5-ASA), indomethacin and 4-aminobenzoic acid hydrazide (4-ABAH) studied herein.

\section{Results and Discussion}

\subsection{Chemistry}

Cinnamic acid derivatives $\mathbf{2 a - j}$ were obtained in moderate to good yields (51-95\%) from the corresponding 3 -acetamidocoumarins $\mathbf{1 a}-\mathbf{j}$ [29]. Compounds $\mathbf{1} \mathbf{a}-\mathbf{j}$ were synthesized following a reported method [30] with modifications in the quantities of the reagents used and reaction time and starting from glycine instead of $N$-acetylglycine, resulting in higher yields (62-86\%) than those reported elsewhere (40-69\%) [31].

The general procedure to obtain $\mathbf{2 a} \mathbf{a} \mathbf{j}$, as switterions, is shown in Scheme 1, which consists of the microwave-assisted acid hydrolysis of the 3-acetamidocoumarins $1 \mathbf{a}-\mathbf{j}$, followed by neutralization with $\mathrm{NaHCO}_{3}$. The reaction conditions were optimized for each compound since they depend on the nature of the substituent. The concentration of the $\mathrm{H}_{2} \mathrm{SO}_{4}$ aqueous solution, temperature and reaction time are the main factors that determine the progress of the reaction. 
<smiles>CC(=O)Nc1cc2ccc([Te])cc2oc1=O</smiles>

$1 a-j$

G

$\begin{array}{ll}\text { 1a H } & \text { 1b 6-Br } \\ \text { 1c 6-Cl } & \text { 1d 6-F } \\ \text { 1e } 8-O E t & \text { 1f } 7-A c O \\ \text { 1g 6-OMe } & \text { 1h 6-AcO } \\ \text { 1i 6-NO } & \text { 1j 6-NH }{ }_{2}\end{array}$

5-15\%

1. $\mathrm{H}_{2} \mathrm{SO}_{4} \mathrm{v} / \mathrm{v}$

$120-160^{\circ} \mathrm{C}$

15-20 min

$\mathrm{Mw}$

2. $\mathrm{NaHCO}_{3}(\mathrm{aq})$<smiles>[NH3+]C(=O)C(=O)c1ccccc1O</smiles>

$2 a-j$

G (yield \%)

2a H (68)

2c $5-\mathrm{Cl}(63)$

2e 3-OEt (82)

2g 5-OMe (74)

2i $5-\mathrm{NO}_{2}(86)$ 2b $5-\mathrm{Br}(51)$

2d 5-F (75)

$2 f 4-\mathrm{OH}(67)$

2h 5-OH (95)

2j $5-\mathrm{NH}_{2}(56)$

Scheme 1. Microwave-assisted hydrolysis of acetamidocoumarins 1a-j to produce (E)-2-hydroxy- $\alpha$-aminocinnamic acids $\mathbf{2} \mathbf{a}-\mathbf{j}$.

The ${ }^{1} \mathrm{H}-\mathrm{NMR}$ spectra of the isolated reaction mixtures, for the conversion of compound $1 \mathrm{f}$ to $2 \mathrm{f}$ at $120{ }^{\circ} \mathrm{C}$ and $5 \% \mathrm{v} / \mathrm{v}$ concentration of $\mathrm{H}_{2} \mathrm{SO}_{4}$ in water, with increasing reaction times, are shown in Figure 2. The complete conversion required $15 \mathrm{~min}$ of reaction at the specified conditions, however, this set of spectra allows us to observe the reaction intermediates. After $5 \mathrm{~min}$ of reaction time, the hydrolyzed ester $\mathbf{I}-\mathbf{f}$ and the aminocoumarin II-f are observed. The mixture progresses to the complete lactone ring opening, leading to compound $\mathbf{2 f}$. The above result confirms that compound $\mathbf{2 f}$ can also be obtained starting from the corresponding aminocoumarin, as sketched in Scheme 2. A summary of the optimized reaction conditions is listed in Table 1. In general, milder conditions are required for acetamidocoumarins substituted with electron-donating groups in comparison to those substituted with electron-withdrawing groups.

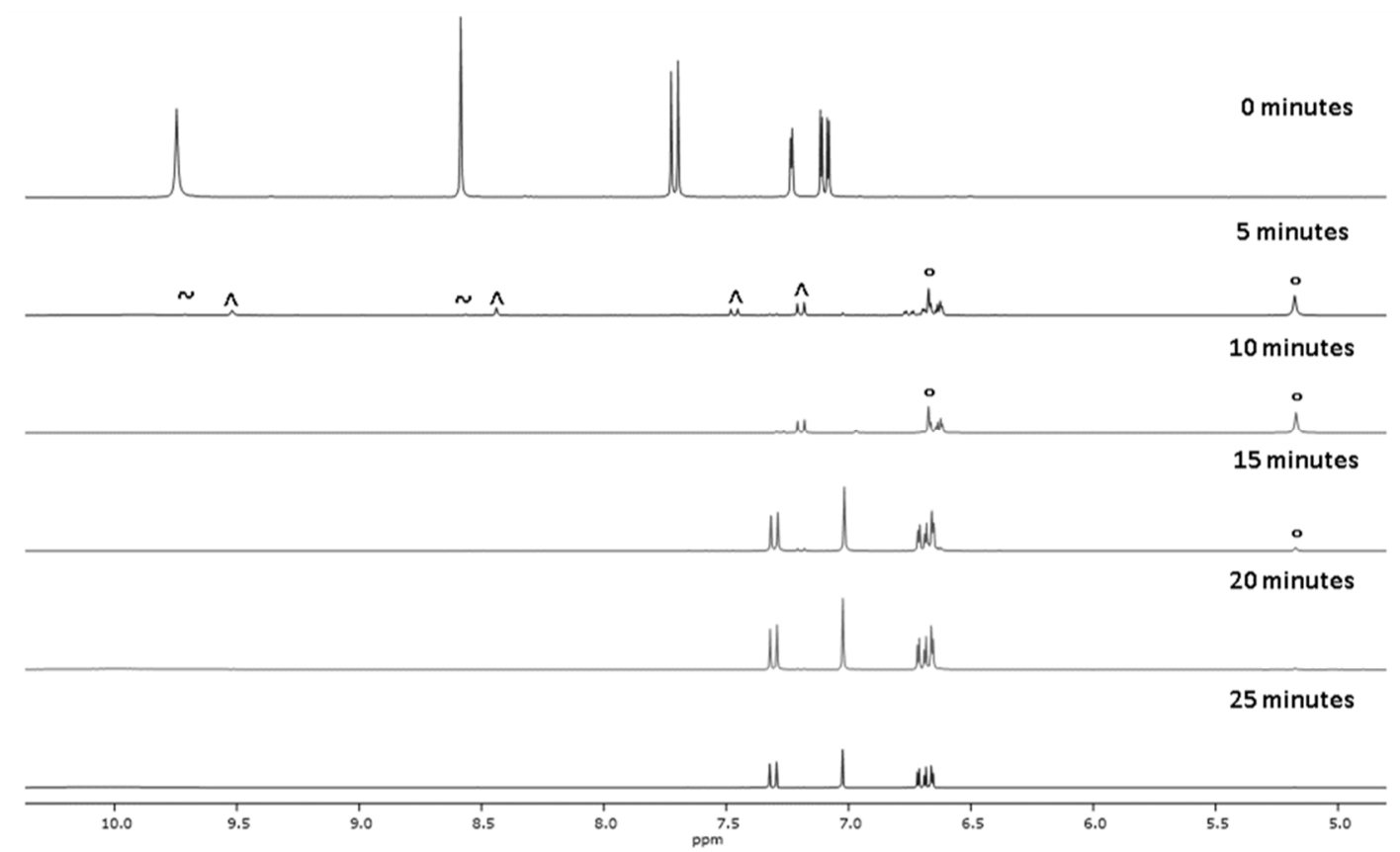

Figure 2. ${ }^{1} \mathrm{H}-\mathrm{NMR}$ spectra (DMSO-d6) showing the effect of reaction time on the conversion of the starting compound $\mathbf{1 f}(\sim)$ to $\mathbf{2 f}$, at a reaction temperature of $120{ }^{\circ} \mathrm{C}$ and $5 \% v / v$ of $\mathrm{H}_{2} \mathrm{SO}_{4}$ in water. The intermediates I-f $\left({ }^{\wedge}\right)$ and II-f $\left(^{\circ}\right)$ are observed in 5 min of reaction time. 
<smiles>CC(=O)Nc1cc2ccc(OC(C)=O)cc2oc1=O</smiles>

Scheme 2. Observed intermediates I-f and II-f in the acid hydrolysis of $\mathbf{1 f}$ to $\mathbf{2 f}$.

Table 1. Optimized reaction conditions to obtain compounds $\mathbf{2 a} \mathbf{a} \mathbf{2} \mathbf{j}$ using microwaves.

\begin{tabular}{cccc}
\hline \multirow{2}{*}{ Compounds } & \multicolumn{3}{c}{ Reaction Conditions } \\
\cline { 2 - 4 } & $\begin{array}{c}\text { Aq. } \mathbf{H}_{\mathbf{2}} \mathbf{S O}_{\mathbf{4}} \text { conc. } \\
\mathbf{( \%} \mathbf{v} / \mathbf{v})\end{array}$ & $\begin{array}{c}\text { Temperature } \\
\left({ }^{\circ} \mathbf{C}\right)\end{array}$ & $\begin{array}{c}\text { Time } \\
(\mathbf{m i n})\end{array}$ \\
\hline $\mathbf{2} \mathbf{f}$ & 5 & 120 & 15 \\
\hline $\mathbf{2 a}, \mathbf{2 e}, \mathbf{2} \mathbf{g}, \mathbf{2 h}, \mathbf{2} \mathbf{j}$ & 15 & 120 & 15 \\
\hline $\mathbf{2 b}, \mathbf{2} \mathbf{c}, \mathbf{2} \mathbf{d}, \mathbf{2} \mathbf{i}$ & 15 & 160 & 20 \\
\hline
\end{tabular}

One of the characteristic structural features of compounds $2 \mathbf{a}-\mathbf{j}$ is the ${ }^{1} \mathrm{H}-\mathrm{NMR}$ signal of the vinyl proton $\mathrm{H7}$, as shown in Scheme 1. It appears in the 6.95-7.26 ppm range as a singlet, which in the corresponding spectra of the starting $\mathbf{1 a}-\mathbf{j}$, is shifted to higher frequencies, usually beyond $8.60 \mathrm{ppm}$ [32] and in the aminocoumarins it appears at lower frequencies in the 6.59-6.71 ppm range [29]. The synthesis of 3-aminocoumarins, by the acid hydrolysis of 3-acetamidocoumarins, has been reported elsewhere [29], using $\mathrm{H}_{2} \mathrm{SO}_{4}$ solution (70\%) by both microwaves and reflux. In this context, compounds $\mathbf{2 a}-\mathbf{j}$ are proposed as the natural final product of hydrolysis. However, we observed by ${ }^{1} \mathrm{H}-$ NMR that compounds $\mathbf{2 a}-\mathbf{j}$ are cyclized with dehydration in highly concentrated $\mathrm{H}_{2} \mathrm{SO}_{4}$ solutions to regenerate the corresponding 3-aminocoumarin (Figures S1 and S2). This transformation requires the phenolic $-\mathrm{OH}$ and the $-\mathrm{COOH}$ groups on the same side around the double bond to perform the lactone ring cyclization. This experimental behavior supports the $(E)$ configuration of compounds $\mathbf{2} \mathbf{a}-\mathbf{j}$. The fact that the synthesis of $\mathbf{2} \mathbf{a}-\mathbf{j}$ was carried out successfully even though the $(Z)$ derivatives of the cinnamic acid are reported to naturally occur in low yields or with little stability $[21,22,24]$ points to the amino group as the structural factor that provides the observed stability of $\mathbf{2 a - j}$, particularly allowing the formation of the switterionic form which prevents lactonization to the corresponding aminocoumarin.

\subsection{DPPH and ABTS Free Radical-Scavenging Activity}

The antioxidant activity of the cinnamic derivatives $\mathbf{2} \mathbf{a}-\mathbf{j}$ was evaluated using DPPH and ABTS tests, using 5-ASA as the reference compound. These tests are widely used to evaluate the removal of free radicals from natural and synthetic compounds; the results of both tests are depicted in Figure 3. In general, the antioxidant capacity evaluated through the DPPH test, using the highest tested concentration of $0.32 \mathrm{mM}$ (see the complete results in Figures S3 and S4), decreased in the following order: 5-ASA $=\mathbf{2 i}>\mathbf{2} \mathbf{f}=\mathbf{2 h}>\mathbf{2} \mathbf{g}>\mathbf{2} \mathbf{j}>\mathbf{2 e}$ $>\mathbf{2 b}=\mathbf{2} \mathbf{c}>\mathbf{2 a}>\mathbf{2} \mathbf{d}$. The radical scavenging activity (RSA) of compound $\mathbf{2 i}$ is the same of 5ASA $(p<0.0001)$ and compounds $\mathbf{2} \mathbf{f}$ and $\mathbf{2 h}$ reach up to $77 \%$ RSA, becoming almost as good as 5-ASA. The value of DPPH RSA of 5-ASA is similar to the reported values of $85-90 \%$ at $0.1-1.0 \mathrm{mM}$ concentrations [33] and $80-85 \%$ at $0.20-0.41 \mathrm{mM}$ concentrations [9]. The performances of compounds $\mathbf{2 f}, \mathbf{2} \mathbf{h}$ and $\mathbf{2 i}$ in the DPPH test are comparable to resveratrolsalicylate analogs (90\% RSA, $0.20 \mathrm{mM}$ ) [34] and caffeic acid (94\% RSA, $0.11 \mathrm{mM})$ [35], the latter being considered by some as the best cinnamic acid antioxidant [36]. 


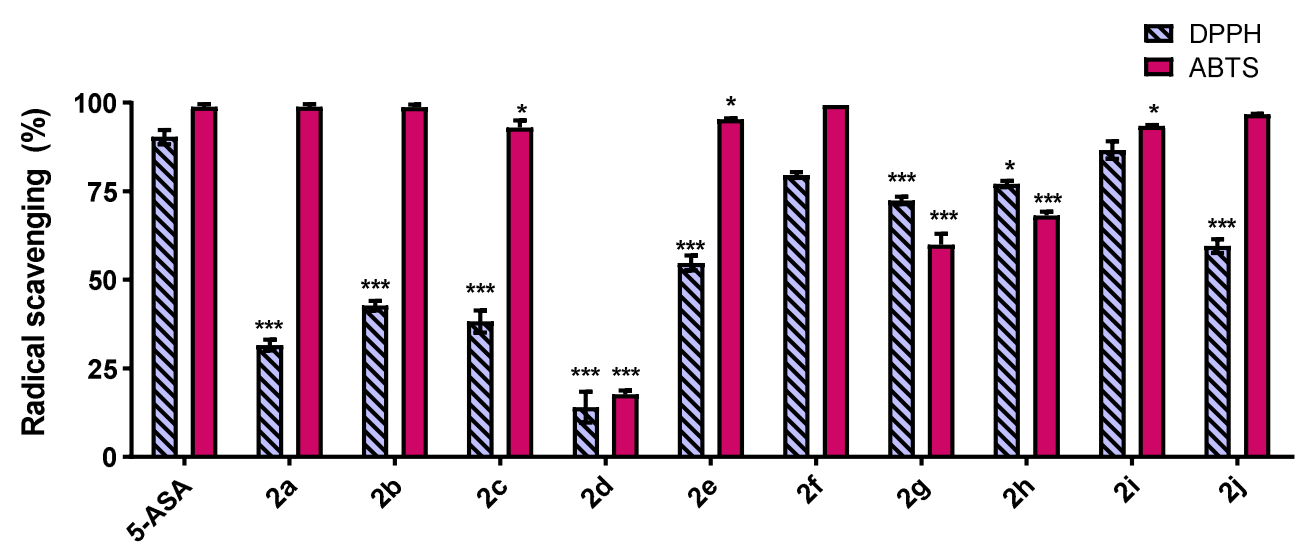

Figure 3. Comparison of the radical-scavenging activity of compounds $\mathbf{2 a}-\mathbf{j}$ vs. 5-ASA at a concentration of $0.32 \mathrm{mM}$ and $0.04 \mathrm{mM}$ in the DPPH and ABTS assays, respectively $\left({ }^{*} p<0.05,{ }^{* * *} p<0.0001\right)$. The assays were performed in triplicate. DPPH RSA (\%): $31.6 \pm 2.6$ (2a), $42.7 \pm 2.4$ (2b), $38.3 \pm 5.4$ (2c), $14.1 \pm 7.5$ (2d), $54.8 \pm 3.7$ (2e), $79.6 \pm 1.4(\mathbf{2 f}), 72.5 \pm 1.8$ (2g), $77.1 \pm 1.5$ (2h), $86.7 \pm 4.3(\mathbf{2 i}), 59.5 \pm 3.4(\mathbf{2 j})$ and $90.4 \pm 3.4$ (5-ASA). ABTS RSA (\%): $98.9 \pm 1.3$ (2a), $98.7 \pm 1.2(\mathbf{2 b})$, $93.1 \pm 3.4(\mathbf{2 c}), 17.7 \pm 2.0(\mathbf{2 d}), 95.4 \pm 0.4(\mathbf{2 e}), 99.4 \pm 0.0,(\mathbf{2 f}), 60.0 \pm 5.3(\mathbf{2 g}), 68.3 \pm 1.8(\mathbf{2 h}), 93.5 \pm 0.4(\mathbf{2 i}), 96.8 \pm 0.3(\mathbf{2 j})$ and $98.9 \pm 1.3(5-A S A)$.

On the other hand, compounds $\mathbf{2 a}, \mathbf{2} \mathbf{b}, \mathbf{2} \mathbf{f}$ and $\mathbf{2} \mathbf{j}$ exhibited $\approx 100 \%$ of RSA at $0.04 \mathrm{mM}$ in the ABTS test, being as active as 5-ASA $(p<0.0001)$. The herein obtained value of ABTS RSA of 5-ASA is similar to the reported value of $98 \%$ at $0.05 \mathrm{Mm}$ [9]. Compounds $2 \mathbf{c}, 2 \mathbf{e}$ and $2 \mathbf{i}$ are within the $93.1-95.4 \%$ range, $2 \mathrm{~g}$ and $2 \mathrm{~h}$ are in the $60.0-68.3 \%$ range and the less effective $\mathbf{2 d}$ has $17.7 \%$ RSA (see the complete results in Figures S5 and S6). Therefore, their performance in the ABTS test is better than the reported values for caffeic (93\% RSA, $0.14 \mathrm{mM}$ ) [35] (45\% RSA, $0.01 \mathrm{mM})$, sinapic $(50 \%, 0.01 \mathrm{mM})$ and ferulic $(40 \%, 0.01 \mathrm{mM})$ acids [37].

Compounds $2 \mathbf{f}-\mathbf{j}$ show performances higher than $60 \%$ in both the DPPH and ABTS antioxidant tests; all of them are substituted with electron-donating groups with the exception of compound $\mathbf{2} \mathbf{i}\left(5-\mathrm{NO}_{2}\right)$. In general, the RSAs of compounds $\mathbf{2 a}-\mathbf{j}$ are related to the possibility of $\pi$-type delocalization of the unpaired electron in the whole structure. In particular, the role played by the exocyclic conjugated double bond, carboxylic acid and the $-\mathrm{NH}_{2}$ group in the stabilization of the 2-OH radical is depicted in Figure 4a. Further, the highest antioxidant ability of $\mathbf{2} \mathbf{f}$ is explained by the radical delocalization of the 4-OH group into the $\alpha$-aminopropenoic fragment, Figure $4 \mathrm{~b}$. Compound $2 \mathrm{~h}$ is structurally comparable with synthetic salicylate derivatives whose RSA performance was demonstrated to depend on the 1,4-disposition between the two-OH groups in the molecule $[33,34]$. The stabilizing resonance structures, including the oxidation products of compound $\mathbf{2 h}$, are depicted in Figure $4 \mathrm{c}$, ending with the formation of quinoid type products which can act as cytotoxic agents in diseases such as cancer, as reported for caffeic acid [38]. The results herein obtained are in agreement with those which point out that at last two phenolic $-\mathrm{OH}$ groups are required to confer antioxidant properties, but this quality is more dependent on their relative disposition [36]. Finally, the RSA of compound 2i, substituted with the strong electro-withdrawing nitro group, is due to the increased acidity of the 2-OH group, facilitating the radical formation and also stabilizing it, Figure $4 \mathrm{~d}$. It is worth noting that the fluorine atom (2d) has the worst RSA in both DPPH and ABTS tests, in contrast to theoretical predictions (vide infra). This behavior could be associated with the high electronegativity of the fluorine atom, accompanied by its limited electronic delocalization possibilities. 
(a)

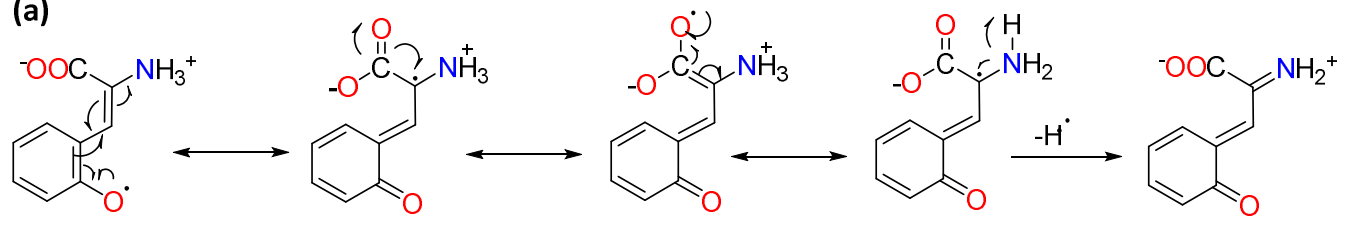

(b)<smiles></smiles>

(c)<smiles>COc1ccc(O)c(C=C([NH3+])C(=O)[O-])c1</smiles>

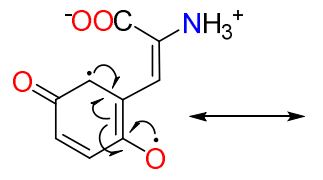<smiles>[NH3+]C(=CC1=CC(=O)C=CC1=O)C(=O)[O-]</smiles>

(d)<smiles>[NH3+]C(=CC1=CC(=N[O-])C=CC1=O)C(=O)[O-]</smiles>

Figure 4. Resonant contributors to the stabilization of free radicals in compounds (a) $2 \mathbf{a},(\mathbf{b}) \mathbf{2 f}$, (c) $2 \mathbf{h}$ and (d) $2 \mathbf{i}$.

\subsection{Molecular Orbital Calculations and Antioxidant Mechanism}

The DPPH and ABTS tests are useful colorimetric probes accepting hydrogen atoms or electrons supplied by the antioxidant compounds. However, none of them allow discriminating between the hydrogen atom transfer (HAT) and single electron transfer (SET) as the most accepted mechanisms for phenols [39]. In this context, theoretical calculations at the B3LYP/6-31 + G(d,p) level of theory were performed in order to gain a better understanding of the operating antioxidant mechanism of compounds $\mathbf{2} \mathbf{a}-\mathbf{j}$. The bond dissociation enthalpy of the 2-OH group $\left(\mathrm{BDE}_{\mathrm{OH}}\right)$, the ionization potential (IP), $\mathrm{E}_{\mathrm{H}}$ (energy of the HOMO), $\mathrm{E}_{\mathrm{L}}$ (energy of LUMO) and $\triangle \mathrm{E}_{\mathrm{H}-\mathrm{L}}$ (HOMO-LUMO gap) in vacuum were calculated. The results are shown in Table 2. 5-ASA was used as the reference compound to determine the reliability of our calculations. All the calculated values for 5-ASA are in agreement with the reported ones [33].

$\mathrm{BDE}_{\mathrm{OH}}$ is related to the HAT mechanism. It describes the thermodynamic stability of the $\mathrm{O}-\mathrm{H}$ bond and small $\mathrm{BDE}_{\mathrm{OH}}$ values are associated with increased susceptibility to homolytic $\mathrm{O}-\mathrm{H}$ bond dissociation. The calculated $\mathrm{BDE}_{\mathrm{OH}}$ values for compounds $\mathbf{2} \mathbf{a}-\mathbf{2} \mathbf{j}$ are in the $52.99-81.13 \mathrm{kcal} \mathrm{mol}^{-1}$ range. The smallest value of $52.99 \mathrm{kcal} \mathrm{mol}^{-1}$ associated with the bromine compound $\mathbf{2 b}$ is underestimated and therefore omitted from discussion. Then, compounds $\mathbf{2} \mathbf{d}>\mathbf{2} \mathbf{a}>\mathbf{2} \mathbf{e}>\mathbf{2} \mathbf{h}>\mathbf{2} \mathbf{f}$ can be ranked as the most active (BDE $\mathrm{OH}_{\text {values }}$ in the 61.95-65.50 range), followed by the less active $\mathbf{2 g}>\mathbf{2 c}>\mathbf{2} \mathbf{i}>\mathbf{2 j}$ (BDE $\mathrm{OH}$ values in the 73.01-81.13 range) through the HAT mechanism. The values for the most active group are smaller than those reported for caffeic acid (72.25-73.95 kcal mol $\left.{ }^{-1}\right)$, ferulic acid (81.36-75.08 $\left.\mathrm{kcal} \mathrm{mol}^{-1}\right)$ and $p$-coumaric acid (81.18 -79.86 $\left.\mathrm{kcal} \mathrm{mol}^{-1}\right)$ [40,41] and even smaller than ascorbic acid $\left(75.4 \mathrm{kcal} \mathrm{mol}^{-1}\right)$ [42]. As far as we are concerned, these values are among the smallest reported for antioxidant compounds [43], indicating a great propensity to react by the HAT mechanism. The OR $(\mathrm{R}=\mathrm{H}, \mathrm{Me}, \mathrm{Et})$ groups favor small $\mathrm{BDE}_{\mathrm{OH}}$ values of the 2-OH: the $5-\mathrm{OH}(\mathbf{2 h})$ group is better than $4-\mathrm{OH}(\mathbf{2 f})$ and the OR group is also more favorable in C-3 (2e) than in C-5 $(\mathbf{2 g})$. These structure trends are in agreement with those observed by others in hydroxycinnamic acids [44].

IP describes the ability of compounds in electron donation, and smaller values of IP are related to a more active SET mechanism [45]. In this context, compounds $\mathbf{2 a - 2} \mathbf{j}$ 
can be sorted into three groups according to their calculated IP values. The most active group through the SET mechanism is represented by $\mathbf{2} \mathbf{f}>\mathbf{2} \mathbf{e}>\mathbf{2 h}>\mathbf{2 a}$, a moderately active group by the halogen substituted compounds $\mathbf{2} \mathbf{b}-\mathbf{2} \mathbf{d}$ and the less active group by $\mathbf{2} \mathbf{j}>\mathbf{2} \mathbf{i}$ $>2 \mathrm{~g}$, showing IP values in the 135.67-138.84, 141.24-145.54 and 150.22-156.95 kcal mol $\mathrm{m}^{-1}$ ranges, respectively. The IP values of the first group of compounds are similar to $p$ coumaric acid (130.43 $\left.\mathrm{kcal} \mathrm{mol}^{-1}\right)$ and other cinnamic acids [44], but smaller than ascorbic acid (152.0 kcal mol$\left.{ }^{-1}\right)$ or cinnamaldehyde (154.9 $\left.\mathrm{kcal} \mathrm{mol}^{-1}\right)$ [46], pointing to the good propensity of $\mathbf{2 a}, \mathbf{2} \mathbf{e}, \mathbf{2} \mathbf{f}$ and $\mathbf{2 h}$ to act through the SET mechanism.

In addition, $\mathrm{E}_{\mathrm{H}}, \mathrm{E}_{\mathrm{L}}$ and $\Delta \mathrm{E}_{\mathrm{H}-\mathrm{L}}(\mathrm{HOMO}-\mathrm{LUMO}$ gap) values are related to the chemical reactivity of the molecule. The lower the $\Delta \mathrm{E}_{\mathrm{H}-\mathrm{L}}$ value, the easier the electronic transition from ground state to excited state and the higher the chemical reactivity. The calculated $\Delta \mathrm{E}_{\mathrm{H}-\mathrm{L}}$ value of compound $\mathbf{2} \mathbf{i}$ is the smallest $(3.92 \mathrm{eV})$, but comparable to the value of 5-ASA (3.94 eV) and sinapic acid (3.8 Ev) [45], whereas the $\Delta \mathrm{E}_{\mathrm{H}-\mathrm{L}}$ values of the rest of the compounds are in the 4.53-4.81 eV range, slightly higher than those calculated for natural hydroxycinnamic acids (4.1-4.5 eV).

Table 2. $\mathrm{BDE}_{\mathrm{OH}}, \mathrm{IP}, \mathrm{E}_{\mathrm{H}}, \mathrm{E}_{\mathrm{L}}$ and $\Delta \mathrm{E}_{\mathrm{H}-\mathrm{L}}$ calculated values at $\mathrm{B} 3 \mathrm{LYP} / 6-31+\mathrm{G}(\mathrm{d}, \mathrm{p})$ in vacuum of 5-ASA and compounds $\mathbf{2} \mathbf{a}-\mathbf{j}$.

\begin{tabular}{|c|c|c|c|c|c|}
\hline Comp. & $\mathrm{BDE}_{\mathrm{OH}}\left(\mathrm{kcal} \mathrm{mol}^{-1}\right)$ & IP (kcal mol-1) & $E_{H}(e V)$ & $\mathrm{E}_{\mathrm{L}}(\mathrm{eV})$ & $\Delta \mathrm{E}_{\mathrm{H}-\mathrm{L}}(\mathrm{eV})$ \\
\hline 5-ASA [33] & 92.60 & 165.87 & -5.66 & -1.81 & 3.85 \\
\hline 5-ASA & 95.44 & 165.71 & -5.79 & -1.85 & 3.94 \\
\hline $2 a$ & 62.02 & 138.84 & -5.80 & -1.05 & 4.75 \\
\hline $2 b$ & 52.99 & 141.24 & -5.93 & -1.33 & 4.60 \\
\hline $2 c$ & 75.68 & 143.20 & -5.90 & -1.27 & 4.63 \\
\hline $2 d$ & 61.95 & 145.54 & -5.90 & -1.24 & 4.66 \\
\hline $2 e$ & 62.79 & 134.50 & -5.76 & -0.95 & 4.81 \\
\hline $2 f$ & $\begin{array}{c}65.50 \\
55.14^{\mathrm{a}}\end{array}$ & 135.67 & -5.61 & -0.96 & 4.65 \\
\hline $2 g$ & 73.01 & 156.95 & -5.55 & -1.02 & 4.53 \\
\hline $2 \mathrm{~h}$ & $\begin{array}{c}62.85 \\
53.95^{b}\end{array}$ & 136.42 & -5.58 & -1.05 & 4.53 \\
\hline $2 \mathbf{i}$ & 79.29 & 152.65 & -6.42 & -2.51 & 3.91 \\
\hline $2 j$ & 81.13 & 150.22 & -5.39 & -0.78 & 4.61 \\
\hline
\end{tabular}

In general, the calculated $\mathrm{BDE}_{\mathrm{OH}}$ and $\mathrm{IP}$ values of compounds $\mathbf{2} \mathbf{a}-\mathbf{j}$ are in agreement with a greater propensity to react by the HAT mechanism. However, compounds 2a, 2e, $2 \mathbf{f}$ and $\mathbf{2 h}$ are predicted to be the most active by either of the two mechanisms with larger stabilities than natural hydroxycinnamic acids.

Finally, it is worth mentioning that theoretical calculations predict a strong change in the conformation adopted by the $\alpha$-aminopropenoic acid arm when radicals are formed. The C2-C1-C7-C8 torsion angle changes from the $143-147^{\circ}$ range in $\mathbf{2 a - j}$ to the $20-34^{\circ}$ range in the radicals. Then, the planar $\alpha$-aminopropenoic acid arm and the bent conformation adopted by radicals and cation radicals strongly resemble the structure of the 3-aminocoumarins, favoring the delocalization of the nitrogen atom lone pair to the phenyl ring which might contribute to their stabilization, Figure 5 [45]. A complete list of C2-C1C7-C8 torsion angles is given in Table S1. 


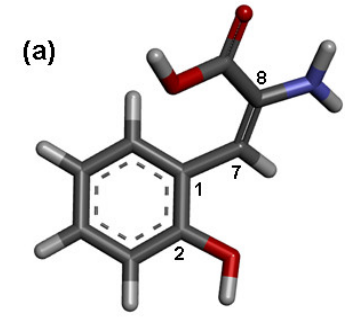

$145.24^{\circ}$ (b)

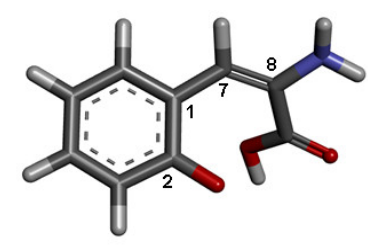

$22.23^{\circ}$ (c)

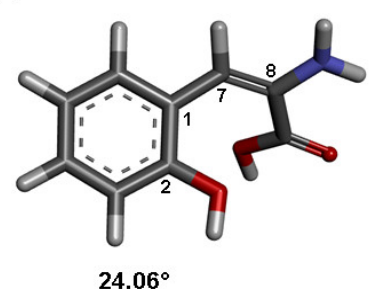

Figure 5. Predicted conformations of (a) 2a, (b) 2a radical and (c) 2a cation radical. The torsion angle C2-C1-C7-C8 is shown.

\subsection{Docking of $\mathbf{2 a - j}$ with $M P O$}

Molecular docking was performed with the aim to support the choice of MPO. Three different conformers of the MPO from molecular dynamics (MD) simulation were used [47]. The validation of the method was carried out with $N$-acetylglucosamine, reaching an RMSD value of $1.194 \AA$ in agreement with accepted values [48] (Figure S7). The calculated binding free energy $(\Delta G)$ and interactions in the binding site are listed in Table 3. In general, the $\Delta \mathrm{G}$ values are more favorable at the MPO conformation adopted at $10 \mathrm{~ns}$ than at 5 or $0 \mathrm{~ns}$ (native structure). The calculated $\Delta \mathrm{G}$ values $\left(\mathrm{kcal} \mathrm{mol}^{-1}\right)$ are in the -6.5 to -6.0 range. The largest values correspond to those compounds bearing halogens $2 \mathbf{b}(5-\mathrm{Br})$ and $\mathbf{2 c}$ (5-Cl). This result contrasts with reported results which mention that halide substituents in tested molecules to inhibit MPO have no effect on it [49]. Docking calculations predict that compounds $\mathbf{2} \mathbf{a}-\mathbf{j}$ bind to the MPO, forming complexes as stable as those of $4-\mathrm{ABAH}$, a well-known irreversible inhibitor, and 5-ASA, the reference compound.

Table 3. Values of $\Delta \mathrm{G}\left(\mathrm{kcal} \mathrm{mol}^{-1}\right)$ of the compounds $\mathbf{2 a}-\mathbf{j}$ in the $10 \mathrm{~ns}$ conformation of the MPO enzyme and their interactions with the amino acid residues.

\begin{tabular}{|c|c|c|}
\hline Comp. & $\Delta \mathrm{G}\left(\mathrm{kcal} \mathrm{mol}^{-1}\right)$ & Interaction Residue \\
\hline 4-АВАН & -6.0 & HEM605, Q91, D94, R239, M243 \\
\hline 5-ASA & -6.1 & HEM605, Q91, D94, R239, E242, M243, L246, H336 \\
\hline $\mathbf{2 a}$ & -6.3 & HEM605, Q91, D94, R239, M243, L246 \\
\hline $2 b$ & -6.5 & HEM605, Q91, D94, R239, M243, L246 \\
\hline 2c & -6.4 & HEM605, Q91, D94, R239, M243, L246 \\
\hline $2 d$ & -6.3 & HEM605, Q91, D94, R239, S240, M243, L246 \\
\hline $2 e$ & -6.3 & HEM605, Q91, D94, R239, E242, M243, L246, H336, F365 \\
\hline $2 f$ & -6.1 & HEM605, Q91, D94, R239, M243, L246, H336 \\
\hline $2 \mathrm{~g}$ & -6.2 & HEM605, Q91, D94, R239, M243, L246 \\
\hline $2 \mathrm{~h}$ & -6.1 & HEM605, Q91, D94, R239, E242, M243, L246, H336, F365 \\
\hline $2 \mathbf{i}$ & -6.3 & HEM605, Q91, D94, R239, M243 \\
\hline $2 j$ & -6.0 & HEM605, Q91, D94, R239, M243, L246 \\
\hline
\end{tabular}

In previous studies [47], the enzyme-binding sites were identified as being formed by the amino acid (aa) residues Q91, H95, R239, D94, F99, E242, R333, F366, F407 and HEM605, where Q91, H95, R239 and four water molecules make up the distal cavity of the MPO, associated with the halogenation cycle. Docking calculations predict that compounds $\mathbf{2 a - j}$, 4-ABAH and 5-ASA interact with the prosthetic heme group (HEM605) and also with the aa residues present in both the main binding site and the distal cavity: Q91, R239, D94, E242 and M243. These results are in agreement with those obtained in silico with triazolopyrimidines which bind into the active site in a reversible manner, avoiding the 
oxidation of the halides by the MPO [50]. The 3D structure of one homodimer of the MPO forming a complex with compound $2 \mathrm{c}$ is depicted in Figure 6, where the type of non-covalent interactions is appreciated.

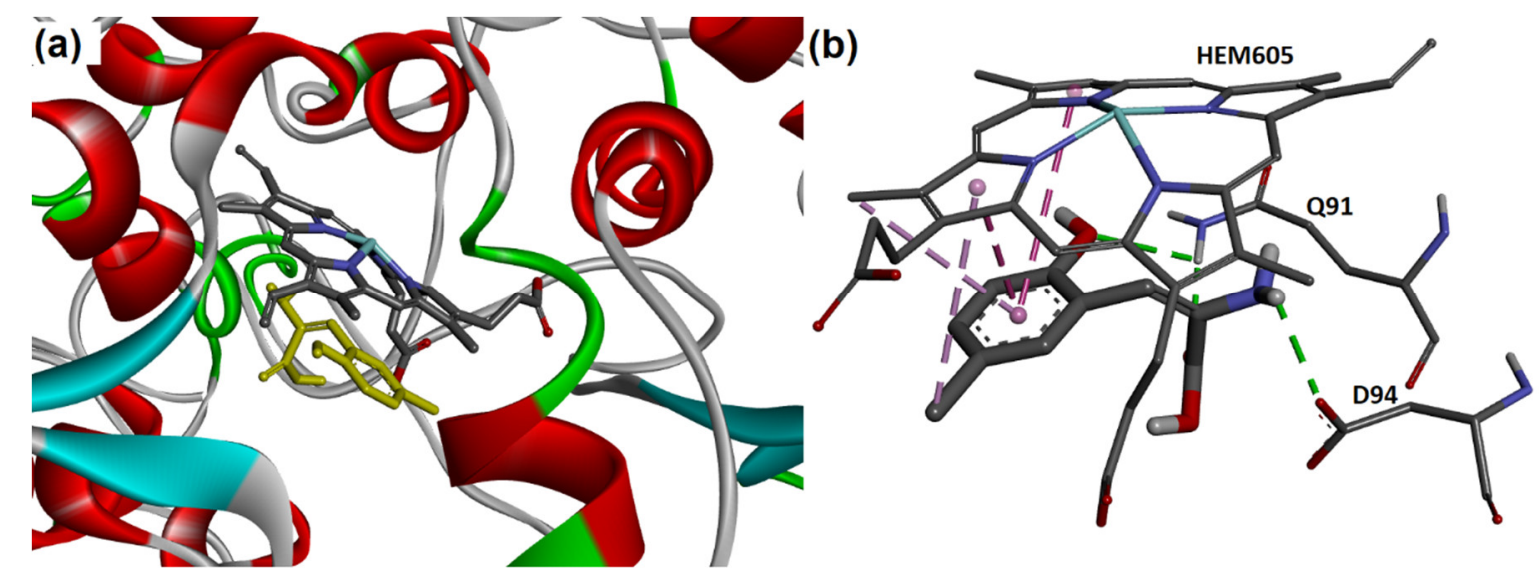

Figure 6. (a) 3D structure of one homodimer of the MPO forming a complex with compound 2c. (b) The main hydrogen bonding interactions, between the carboxylic acid and amino groups with the aa residues glutamine (Q91) and aspartic acid (D94), respectively, in addition to the $\pi$-stacking interaction between 2-hydroxyphenyl ring with the HEM605, are shown.

\subsection{MPO Enzymatic Activity of Peroxidation and Chlorination}

Peroxidation and chlorination enzymatic activities of the MPO, in the presence of compounds $\mathbf{2 a}-\mathbf{j}$, were tested in vitro. The results are shown in Figure 7 . All compounds, with the exception of $\mathbf{2 d}$, inhibit the peroxidation activity of the MPO. An inhibition larger than $50 \%$ is exhibited by compounds $\mathbf{2 a}, \mathbf{2 e}, \mathbf{2 f}$ and $\mathbf{2 h}$ at $100 \mu \mathrm{M}$. Particularly, the inhibition of MPO by $2 \mathbf{e}$ and $2 \mathbf{h}$ reaches values as high as $79 \%$, comparable to 5 -ASA. The $\mathrm{IC}_{50}$ of this set of compounds was estimated using a semi-logarithmic correlation of \% inhibition against the log of the concentration $(3,6,12,25,50,100,200,400 \mu \mathrm{M})$, the dose-response graphs are depicted in Figure S8. There are no significant differences between the $\mathrm{IC}_{50}$ values $(\mu \mathrm{M})$ of $\mathbf{2 f}(30 \pm 5), \mathbf{2 h}(26 \pm 2)$ and indomethacin $(29 \pm 2)$, whose $\mathrm{IC}_{50}$ values are smaller than those corresponding to $\mathbf{2 a}(45 \pm 4), \mathbf{2 e}(43 \pm 4)$ and 5-ASA $(39 \pm 2)$. These results are in agreement with those obtained in DPPH and ABTS tests.

The chlorination test shows that compounds $2 \mathbf{c}, \mathbf{2 f}$ and $\mathbf{2 i}$ exhibit a significant decrease in the enzymatic activity of chlorination, in the range of $20-40 \%$, with $2 \mathrm{c}$ being the best MPO-inhibiting compound, showing the same activity as 5-ASA at $100 \mu \mathrm{M}$, Figure 8 . These results indicate that the analyzed compounds, including 5-ASA, are not specific for MPO inhibition, therefore, they could be good candidates for other peroxidases which do not carry out the halogenation cycle, such as COX inhibitors. 


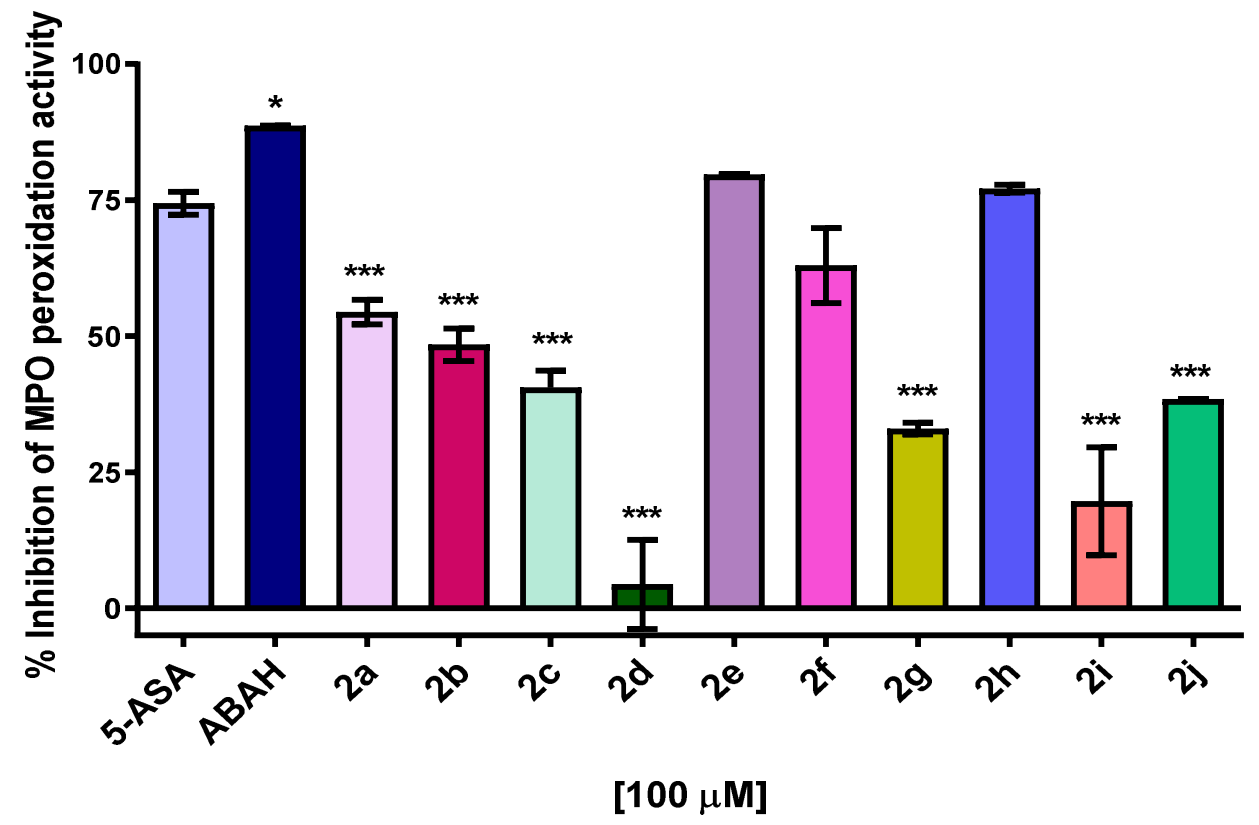

Figure 7. Comparison of the MPO peroxidation inhibitory activity of compounds $\mathbf{2 a - j} \mathbf{j}$ vs. 5 -ASA and 4 -ABAH at $100 \mu \mathrm{M}$ concentration $\left({ }^{*} p<0.05,{ }^{* * *} p<0.001\right)$. The assays were performed in triplicate. Peroxidation inhibition values (\%): $54.4 \pm 3.1$ (2a), $48.4 \pm 4.1$ (2b), $40.5 \pm 4.4$ (2c), $4.3 \pm 0.1$ (2d), $79.7 \pm 6.6(\mathbf{2 e}), 63.0 \pm 1.5(\mathbf{2 f}), 33.0 \pm 1.1(\mathbf{2 g}), 77.1 \pm 3.9(\mathbf{2 h}), 19.6 \pm 0.1(\mathbf{2 i}), 38.3 \pm 0.1(2 \mathbf{j})$ and $74.4 \pm 2.9(5-$ ASA).

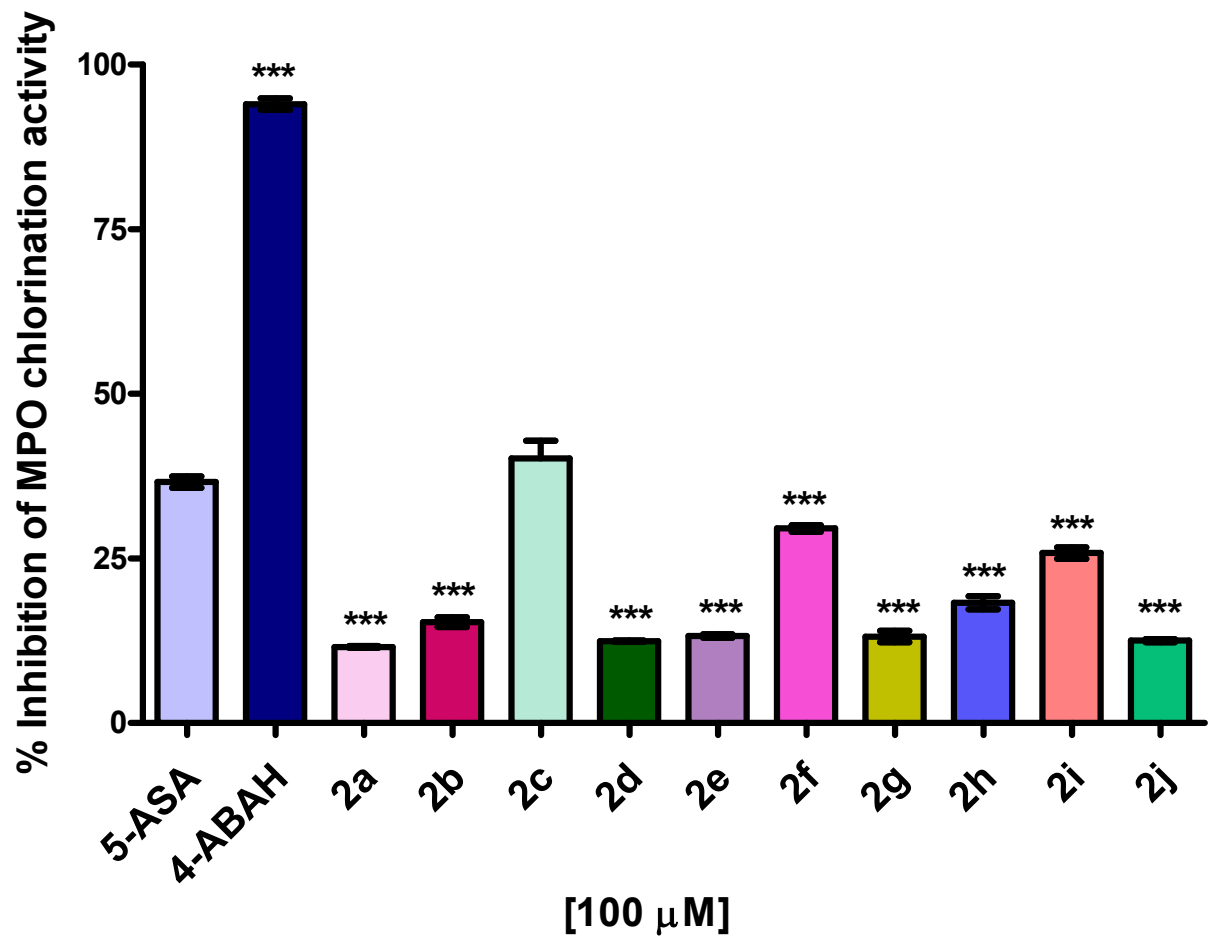

Figure 8. Comparison of the MPO chlorination inhibitory activity of compounds $\mathbf{2 a}-\mathbf{j}$ vs. 5-ASA and $4-\mathrm{ABAH}$ at $100 \mu \mathrm{M}$ concentration $(* * * p<0.001)$. The assays were performed in triplicate. Chlorination inhibition values (\%): $11.6 \pm 0.1$ (2a), $15.3 \pm 0.4(\mathbf{2 b}), 40.2 \pm 1.2(\mathbf{2 c}), 12.4 \pm 0.1(\mathbf{2 d}), 13.2 \pm 0.1$ (2e),

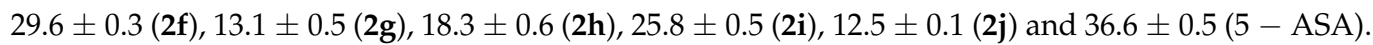




\subsection{Cell Viability}

Compounds $\mathbf{2 a - j}$ exhibit antioxidant capabilities and MPO inhibitory activity. Thus, in order to gain insight into the cytotoxic potential of these derivatives, they were tested at $12.5-200 \mu \mathrm{M}$ on the fibroblast cell line NIH/3T3. The cell viability was measured by performing an MTT assay with the maximum pattern cell activity occurring at $100 \%$ of MTT reduction. Results at 100 and $200 \mu \mathrm{M}$ are shown in Figure 9. The complete data can be found in Table S2. In general, the cytotoxicity of compounds $\mathbf{2 a - 2 i}$ is low. The bromine derivative $\mathbf{2} \mathbf{b}$ was found to be the most cytotoxic, diminishing the cell viability up to $19 \%$ at $200 \mu \mathrm{M}$. The rest of the compounds maintain the cell viability above $85 \%$, and the effect is unrelated to the concentration.

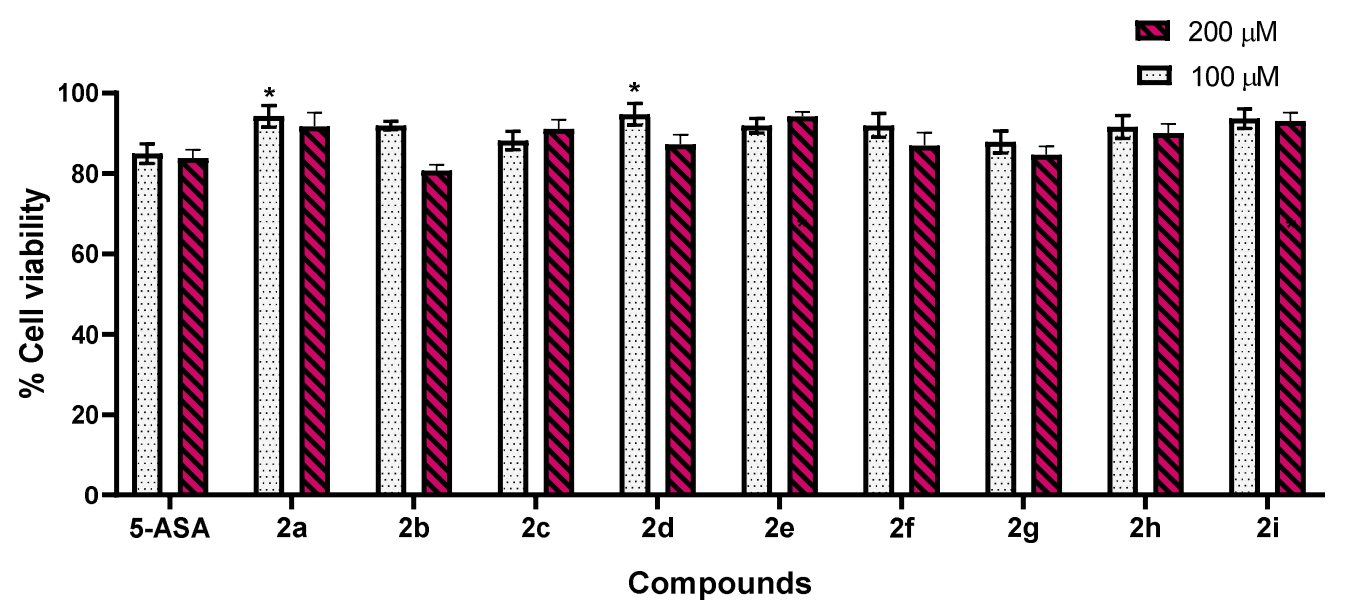

Figure 9. Percentage of cell viability of NIH/3T3 cells after treatment with compounds $2 \mathbf{a}-\mathbf{i}$ at $100-200 \mu \mathrm{M} .{ }^{*} p<0.05$.

\section{Materials and Methods}

Substituted salicylaldehydes, sodium acetate, glycine, acetic anhydride, 2,2-diphenyl1-picrylhydrazyl (DPPH), 2,2-azino-bis(3-ethylbenzothiazolin)-6-sulfonic acid (ABTS), $\alpha$ phenyl- $N$-tert-butylnitrone (PBN), 5-aminosalicylic acid (5-ASA), hydrogen peroxide solution $30 \mathrm{wt} \%$ in $\mathrm{H}_{2} \mathrm{O}$ (ACS reagent), taurine ( $\geq 99 \%$ purity), DTNB ( $\geq 99 \%$ purity), ortho-dianisidine and solvents were analytical grade and used as received (Sigma-Aldrich). Myeloperoxidase of human polymorphonuclear leukocytes (EC number 1.11.1.7, >95\% purity) from Millipore ${ }^{\circledR}$ Merk was used. The synthetic procedures and characterization of compounds $\mathbf{1} \mathbf{a}-\mathbf{j}$ are described in the Supplementary Materials.

The microwave-assisted synthesis of compounds $\mathbf{2 a}-\mathbf{j}$ was carried out in a Monowave 300 synthesis reactor from Anton Paar operating at $850 \mathrm{~W}$. IR spectra were recorded neat at $25^{\circ} \mathrm{C}$ with a Perkin Elmer Spectrum GX series with an FT system spectrophotometer using the ATR device. Melting points were measured in an Electrothermal IA 91000 device. ${ }^{1} \mathrm{H}$ and ${ }^{13} \mathrm{C}$ NMR spectra were acquired on a Varian Mercury NMR spectrometer operating at $300 \mathrm{MHz}\left({ }^{1} \mathrm{H}, 300.08 ;{ }^{13} \mathrm{C}, 75.46 \mathrm{MHz}\right)$ or Bruker Avance DPX-400, using DMSO-d6 as a solvent. All chemical shift values $(\delta)$ are reported in parts per million (ppm), using as a reference the residual solvent peak $\left({ }^{1} \mathrm{H}, \delta 2.50 ;{ }^{13} \mathrm{C}, \delta 39.52\right)$ and coupling constants ${ }^{n} J(\mathrm{H}-\mathrm{H})$ in Hz. Multiplicity of the signals are expressed as: s (singlet), d (doublet), $\mathrm{t}$ (triplet), q (quartet), m (multiplet) or br (broad) (Figures S9-S38).

\subsection{Synthetic Procedures and Characterization of Compounds $\mathbf{2 a}-\mathbf{j}$}

(E)-(2-hydroxy)- $\alpha$-aminocinnamic acid (2a). First, $0.300 \mathrm{~g}$ of $\mathrm{N}$-(2-oxo-2H-chromen-3-yl) acetamide $(1.48 \mathrm{mmol}), 1 \mathrm{a}$, were dissolved in $18 \mathrm{~mL}$ of a recently prepared aqueous $\mathrm{H}_{2} \mathrm{SO}_{4}$ solution of $15 \%(v / v)$ inside a $30 \mathrm{~mL}$ microwave vial. The reaction was allowed to proceed for $15 \mathrm{~min}$ at $120^{\circ} \mathrm{C}$ and $1200 \mathrm{rpm}$. Thereafter, the reaction was neutralized with $\mathrm{NaHCO}_{3}(0.70 \mathrm{~g})$, and the resulting solid was then filtered and washed with distilled water $(10 \mathrm{~mL})$ to afford $\mathbf{2 a}$ as a white powder in $68 \%$ yield $(0.180 \mathrm{~g}, 1.00 \mathrm{mmol}), \mathrm{m} . \mathrm{p} .202{ }^{\circ} \mathrm{C}$, Rf: 
0.68 hexane/ethyl acetate (AcOEt) 1:1. ${ }^{1} \mathrm{H}-\mathrm{NMR} \delta: 7.46\left(\mathrm{dd}, 1 \mathrm{H},{ }^{3} \mathrm{~J}=7.5, \mathrm{H} 6\right), 7.26(\mathrm{~m}, 2 \mathrm{H}$, H5,3), 7.23 (m, 1H, H4), 6.95 (s, 1H, H7). ${ }^{13}$ C-NMR 8: 161.0 (C=O), 148.7 (C2), 146.5 (C8), 126.0 (C4), 125.7 (C6), 124.9 (C5), 123.12 (C1), 115.9 (C3), 112.3 (C7). IR ( $\left.\mathrm{cm}^{-1}\right): 3043(\mathrm{~N}-\mathrm{H})$, $1681(\mathrm{C}=\mathrm{O}), 1456,735$.

(E)-(5-Bromo-2-hydroxy)- $\alpha$-aminocinnamic acid (2b). The synthesis was carried out as previously indicated for derivative $\mathbf{2 a}$, starting from $0.300 \mathrm{~g}(1.06 \mathrm{mmol})$ of $\mathbf{1 b}$ under the following conditions: $160{ }^{\circ} \mathrm{C}$ for $20 \mathrm{~min}$, to yield $0.140 \mathrm{~g}(0.540 \mathrm{mmol}, 51 \%)$ of a brown solid, m.p. $243{ }^{\circ} \mathrm{C}$, Rf: 0.76 hexane/AcOEt 1:1. ${ }^{1} \mathrm{H}-\mathrm{NMR} \delta: 7.82\left(\mathrm{~d}, 1 \mathrm{H},{ }^{4} \mathrm{~J}=2.3, \mathrm{H} 6\right), 7.52$ $\left(\mathrm{dd}, 1 \mathrm{H},{ }^{3} \mathrm{~J}=8.6,{ }^{4} \mathrm{~J}=2.5, \mathrm{H} 4\right), 7.31\left(\mathrm{~d}, 1 \mathrm{H},{ }^{3} \mathrm{~J}=8.7, \mathrm{H} 3\right), 7.09(\mathrm{~s}, 1 \mathrm{H}, \mathrm{H} 7) 10.7(\mathrm{~s}, 1 \mathrm{H}, \mathrm{OH})$. NMR ${ }^{13} \mathrm{C}$ 8: 158.3 (C=O), 148.6 (C2), 143.0 (C8), 130.4 (C4), 128.8 (C6), 123.3 (C1), 118.3 (C5), 116.8 (C3), 114.0 (C7). IR ( $\left.\mathrm{cm}^{-1}\right): 3355(\mathrm{~N}-\mathrm{H}), 1690(\mathrm{C}=\mathrm{O}), 1384,771$.

(E)-(5-Chloro-2-hydroxy)- $\alpha$-aminocinnamic acid (2c). The synthesis was carried out as previously indicated for derivative $\mathbf{2 b}$, starting from $0.300 \mathrm{~g}(1.26 \mathrm{mmol})$ of $\mathbf{1 c}$ to yield $0.170 \mathrm{~g}$ $(0.790 \mathrm{mmol}, 63 \%)$ of a brown solid, m.p. $252{ }^{\circ} \mathrm{C}$, Rf: 0.81 hexane/AcOEt 1:1. ${ }^{1} \mathrm{H}-\mathrm{NMR}$ : $\delta 10.7(\mathrm{br}, 1 \mathrm{H}, \mathrm{OH}), 7.64\left(\mathrm{~d}, 1 \mathrm{H},{ }^{4} \mathrm{~J}=2.0, \mathrm{H} 6\right), 7.09(\mathrm{~s}, 1 \mathrm{H}, \mathrm{H} 7), 7.39(\mathrm{~m}, 2 \mathrm{H}, \mathrm{H} 4,3) .{ }^{13} \mathrm{C}-\mathrm{NMR}:$ $\delta 158.3$ (C=O), 148.1 (C2), 143.0 (C8), 128.9 (C5), 127.6 (C4), 125.8 (C6), 122.8 (C1), 117.9 (C3), 114.1 (C7). IR cm ${ }^{-1}$ : 3381 (N-H), 1720 (C=O), 1518, 919, 835.

(E)-(5-Fluoro-2-hydroxy)- $\alpha$-aminocinnamic acid (2d). It was synthesized as indicated for compound $\mathbf{2 b}$, starting from $0.300 \mathrm{~g}(1.36 \mathrm{mmol}) \mathbf{1 d}$ to yield $0.200 \mathrm{~g}(1.01 \mathrm{mmol}, 75 \%)$ of a brown solid m.p. $242{ }^{\circ} \mathrm{C}$, Rf: 0.84 hexane/AcOEt 1:1. ${ }^{1} \mathrm{H}-\mathrm{NMR}: \delta 7.43\left(\mathrm{dd},{ }^{3} J_{\mathrm{H}-\mathrm{F}}=9.1\right.$, $\left.{ }^{4} \mathrm{~J}=3, \mathrm{H} 6\right), 7.39\left(\mathrm{dd},{ }^{4} J_{\mathrm{H}-\mathrm{F}}=5,{ }^{3} \mathrm{~J}=9.1, \mathrm{H} 3\right), 7.22\left(\mathrm{ddd},{ }^{3} J_{\mathrm{H}-\mathrm{F}}=9.0,{ }^{3} \mathrm{~J}=8.6,{ }^{4} \mathrm{~J}=3, \mathrm{H} 4\right), 7.08(\mathrm{~s}$, 1H, H7). ${ }^{13}$ C-NMR: $\delta 160.1$ (C=O), $158.5(\mathrm{C} 2), 145.8(\mathrm{C} 8), 143.2(\mathrm{C} 5), 122.6\left({ }^{3} J_{\mathrm{C}-\mathrm{F}}=10.3, \mathrm{C} 1\right)$, $117.8\left({ }^{3} J_{\mathrm{C}-\mathrm{F}}=9.1, \mathrm{C} 3\right), 114.8\left({ }^{2} J_{\mathrm{C}-\mathrm{F}}=24.8, \mathrm{C} 4\right), 114.3(\mathrm{C} 7), 112.0\left({ }^{2} J_{\mathrm{C}-\mathrm{F}}=25, \mathrm{C} 6\right) . \mathrm{IR} \mathrm{cm}^{-1}$ : $3115(\mathrm{~N}-\mathrm{H}), 1676(\mathrm{C}=\mathrm{O}), 1518,748$.

(E)-(3-Ethoxy-2-hydroxy)- $\alpha$-aminocinnamic acid (2e). It was synthesized as indicated for compound $2 \mathbf{a}$, starting from $0.300 \mathrm{~g}(1.20 \mathrm{mmol})$ of $1 \mathbf{e}$ to yield $0.220 \mathrm{~g}(0.990 \mathrm{mmol}, 82 \%)$ of a brown solid, m.p. $139{ }^{\circ} \mathrm{C}$, Rf: 0.70 hexane/AcOEt 1:1. ${ }^{1} \mathrm{H}-\mathrm{NMR}: \delta 10.4(\mathrm{br}, 1 \mathrm{H}, \mathrm{OH}), 7.16$ $\left(\mathrm{t}, 1 \mathrm{H},{ }^{3} \mathrm{~J}=8.1, \mathrm{H} 5\right), 7.07(\mathrm{~s}, 1 \mathrm{H}, \mathrm{H} 7), 7.04(\mathrm{~m}, 2 \mathrm{H}, \mathrm{H} 4,6), 4.11\left(\mathrm{c}, 2 \mathrm{H}, \mathrm{CH}_{2},{ }^{3} \mathrm{~J}=7.0\right), 1.37(\mathrm{t}$, $\left.3 \mathrm{H}, \mathrm{CH}_{3},{ }^{3} \mathrm{~J}=7.0\right) .{ }^{3}{ }^{3} \mathrm{C}-\mathrm{NMR}: \delta 158.6(\mathrm{C}=\mathrm{O}), 145.9(\mathrm{C} 2), 142.3(\mathrm{C} 8), 138.7(\mathrm{C} 3), 125.0(\mathrm{C} 6)$, 121.7 (C1), 118.1 (C5), 115.5 (C7), $111.4(\mathrm{C} 4), 64.5\left(\mathrm{CH}_{2}\right), 15.0\left(\mathrm{CH}_{3}\right) . \mathrm{IR} \mathrm{cm}^{-1}$ : $3352(\mathrm{~N}-\mathrm{H}$, $1692(\mathrm{C}=\mathrm{O}), 1472,764$.

(E)-(2,4-dihydroxy)- $\alpha$-aminocinnamic acid (2f). It was synthesized as indicated for compound 2a, starting from $0.300 \mathrm{~g}(1.15 \mathrm{mmol})$ of compound $\mathbf{1 f}$ and $18 \mathrm{~mL}$ of a $5 \% v / v \mathrm{H}_{2} \mathrm{SO}_{4}$ solution, at $120^{\circ} \mathrm{C}, 10 \mathrm{~min}$ to yield $0.180 \mathrm{~g}(0.920 \mathrm{mmol}, 67 \%)$ of a brown solid, m.p. $272{ }^{\circ} \mathrm{C}$, Rf: 0.77 hexane/ AcOEt 1:1. ${ }^{1} \mathrm{H}-\mathrm{NMR}: \delta 10.0(\mathrm{br}, 2 \mathrm{H}, \mathrm{OH}), 7.35\left(\mathrm{~d}, 1 \mathrm{H},{ }^{3} \mathrm{~J}=8.5, \mathrm{H} 6\right), 7.06(\mathrm{~s}$, $1 \mathrm{H}, \mathrm{H} 7), 6.74\left(\mathrm{dd}, 1 \mathrm{H},{ }^{3} \mathrm{~J}=8.5,{ }^{4} \mathrm{~J}=2.3, \mathrm{H} 5\right), 6.69\left(\mathrm{~d}, 1 \mathrm{H},{ }^{4} \mathrm{~J}=2.3, \mathrm{H} 3\right) .{ }^{13} \mathrm{C}$ NMR: $\delta 159.2$ (C=O), 158.2 (C2), 151.0 (C4), 139.1 (C8), 127.7 (C6), 116.6 (C7), 113.6 (C5), 112.7 (C1), 102.4 (C3). IR cm ${ }^{-1}$ : 3278 (OH, N-H), 1696 (C=O), 1454, 826.

(E)-(2-hydroxy-5-methoxy)- $\alpha$-aminocinnamic acid (2g). It was synthesized as indicated for compound $2 \mathrm{a}$, starting with $0.300 \mathrm{~g}(1.29 \mathrm{mmol})$ of $1 \mathrm{~g}$ to yield $0.200 \mathrm{~g}(0.95 \mathrm{mmol}, 74 \%)$ of a brown solid. m.p. $154{ }^{\circ} \mathrm{C}$, Rf: 0.67 hexane/AcOEt 1:1. ${ }^{1} \mathrm{H}-\mathrm{NMR}: \delta 10.4(\mathrm{br}, 1 \mathrm{H}, \mathrm{OH})$, $7.24\left(\mathrm{~d}, 1 \mathrm{H},{ }^{3} \mathrm{~J}=9.0, \mathrm{H} 4\right), 7.05\left(\mathrm{~d}, 1 \mathrm{H},{ }^{4} J=3.2, \mathrm{H} 6\right), 6.98(\mathrm{~s}, 1 \mathrm{H}, \mathrm{H} 7) 6.93\left(\mathrm{dd}, 1 \mathrm{H},{ }^{3} \mathrm{~J}=8.8\right.$, $\left.{ }^{4} \mathrm{~J}=3.0, \mathrm{H} 3\right), 3.75\left(\mathrm{~s}, 3 \mathrm{H}, \mathrm{CH}_{3}\right) .{ }^{13} \mathrm{C}-\mathrm{NMR}: \delta 159.4\left(\mathrm{CO}_{2}\right), 156.3(\mathrm{C} 2,5), 143.6(\mathrm{C} 8), 122.4(\mathrm{C} 6)$, 116.9 (C7), 114.4 (C4), $114.2(\mathrm{C} 1), 109.1(\mathrm{C} 3), 56.0\left(\mathrm{OCH}_{3}\right) . \mathrm{IR} \mathrm{cm}^{-1}: 3360(\mathrm{~N}-\mathrm{H}), 1680(\mathrm{C}=\mathrm{O})$, $1400,765$.

(E)-(2,5-dihydroxy)- $\alpha$-aminocinnamic acid (2h). It was synthesized as indicated for compound 2a, starting from $0.300 \mathrm{~g}(1.15 \mathrm{mmol})$ of $1 \mathrm{~h}$ to yield $0.200 \mathrm{~g}(1.02 \mathrm{mmol}, 95 \%)$ of a brown solid, m.p. $211{ }^{\circ} \mathrm{C}$. Rf: 0.79 hexane/AcOEt 1:1. ${ }^{1} \mathrm{H}-\mathrm{NMR}: \delta$ 10.2, $9.5(\mathrm{br}, 1 \mathrm{H}$ each, OH), $7.14\left(\mathrm{~d}, 1 \mathrm{H},{ }^{3} \mathrm{~J}=8.7, \mathrm{H} 3\right), 7.00(\mathrm{~s}, 1 \mathrm{H}, \mathrm{H7}), 6.81\left(\mathrm{~d}, 1 \mathrm{H},{ }^{4} \mathrm{~J}=2.6, \mathrm{H} 6\right), 6.76\left(\mathrm{dd}, 1 \mathrm{H},{ }^{3} \mathrm{~J}=8.8\right.$, $\left.{ }^{4} J=2.6, \mathrm{H} 4\right) .{ }^{13} \mathrm{C}-\mathrm{NMR}: \delta 159.4$ (C=O), 154.8 (C2), 143.3 (C8), 143.5 (C5), 122.0 (C1), 117.3 (C3), 116.3 (C4), 115.8 (C7), 111.5 (C6). IR cm ${ }^{-1}$ : 3249 (OH, NH), 1690 (C=O), 1456, 766. 
(E)-(2-hydroxy-5-nitro)- $\alpha$-aminocinnamic acid (2i). It was synthesized as indicated for compound $2 \mathbf{b}$, starting from $0.300 \mathrm{~g}(1.21 \mathrm{mmol})$ of $1 \mathbf{i}$ to yield $0.230 \mathrm{~g}(1.04 \mathrm{mmol}, 86 \%)$ of a brown solid, m.p. $240{ }^{\circ} \mathrm{C}$, Rf: 0.7 hexane/AcOEt 1:1. ${ }^{1} \mathrm{H}-\mathrm{NMR} \delta 8.54\left(\mathrm{~d}, 1 \mathrm{H},{ }^{4} \mathrm{~J}=2.7, \mathrm{H} 6\right)$, $8.16\left(\mathrm{dd}, 1 \mathrm{H},{ }^{3} \mathrm{~J}=8.9,{ }^{4} \mathrm{~J}=2.7, \mathrm{H} 4\right), 7.54\left(\mathrm{~d}, 1 \mathrm{H},{ }^{3} \mathrm{~J}=9.1, \mathrm{H} 3\right), 7.26(\mathrm{~s}, 1 \mathrm{H}, \mathrm{H} 7) .{ }^{13} \mathrm{C}$ NMR: $\delta$ $158.1\left(\mathrm{CO}_{2}\right), 153.4(\mathrm{C} 2), 144.5$ (C8), 143.9 (C5), 122.9 (C4), 122.6 (C6), 122.3 (C1), 117.7 (C3), 114.3 (C7). IR cm ${ }^{-1}: 3456(\mathrm{~N}-\mathrm{H}), 1717(\mathrm{C}=\mathrm{O}), 1518,1343,772$.

(E)-(5-amino-2-hydroxy)- $\alpha$-aminocinnamic acid (2j). It was synthesized as indicated for compound $\mathbf{2 a}$, starting from $0.300 \mathrm{~g}(1.37 \mathrm{mmol})$ of $\mathbf{1 j}$ to yield $0.150 \mathrm{mg}(0.770 \mathrm{mmol}, 56 \%)$ of a brown solid, m.p. $246^{\circ} \mathrm{C}$, Rf: 0.43 hexane/AcOEt 1:1. ${ }^{1} \mathrm{H}-\mathrm{NMR}: \delta 7.07\left(\mathrm{~d}, 1 \mathrm{H},{ }^{3} \mathrm{~J}=8.2, \mathrm{H} 3\right)$, $6.96(\mathrm{~s}, 1 \mathrm{H}, \mathrm{H} 7), 6.67\left(\mathrm{dd}, 1 \mathrm{H},{ }^{3} J=8.2,{ }^{4} J=2.3, \mathrm{H} 4\right), 6.61\left(\mathrm{~d}, 1 \mathrm{H},{ }^{4} J=2.3, \mathrm{H} 6\right) .{ }^{13} \mathrm{C}$ NMR: $\delta$ $158.9\left(\mathrm{CO}_{2}\right), 145.7$ (C2), 141.5 (C8), 141.2 (C5), 121.0 (C7), 116.2 (C3), 115.4 (C1), 115.0 (C4), 108.9 (C6). IR cm ${ }^{-1}$ : 3369 (N-H), $3225(\mathrm{O}-\mathrm{H}), 1719$ (C=O), 1654, 1409, 1200, 117, 1047, 873.

\subsection{DPPH Assay (2,2-Diphenyl-1-picrylhydrazyl)}

One hundred microliters of DPPH $0.20 \mathrm{mM}$ in absolute methanol and $100 \mu \mathrm{L}$ of the appropriate compound $(0.32,0.16,0.08,0.04,0.02,0.01 \mathrm{mM}$ final concentrations) dissolved in DMSO were poured into a 96-well plate. The mixtures were incubated for $30 \mathrm{~min}$ at room temperature and protected from light. The absorbance was recorded at $517 \mathrm{~nm}$ in a transparent 96-well test microplate (Multiskan-EX Thermo Scientific, Thermo Fisher Scientific, Waltham, MA, USA). The results are expressed as percentage of DPPH radical present for each concentration of derivatives. To determine the antioxidant activity of each compound, the percentage of the DPPH radical-scavenging activity was calculated by the following equation: $\left[1-\left(A_{1}-A_{2}\right) /\left(A_{D P P H}-A_{S}\right)\right] \times 100$, where: $A_{1}=$ Absorbance of the compound with DPPH, $\mathrm{A}_{2}=$ Absorbance of the compound, $\mathrm{A}_{\mathrm{DPPH}}=$ Absorbance of DPPH (diluted 1:1 with solvent) and $\mathrm{A}_{\mathrm{S}}=$ Absorbance of DMSO.

\subsection{ABTS Test (2,2-Azino-bis(3-ethylbenzothiazolin)-6-sulfonic Acid)}

ABTS dissolved in water to a $7.00 \mathrm{mM}$ final concentration was allowed to react for $16 \mathrm{~h}$ at room temperature in the dark with an aqueous solution of potassium persulfate $2.45 \mathrm{mM}$ to produce the ABTS radical cation $\left(\mathrm{ABTS}^{+} \bullet\right.$ ) before use. In a 96-well plate, $100 \mu \mathrm{L}$ of the appropriate compound $\mathbf{2 a}-\mathbf{2} \mathbf{j}(0.040,0.020,0.010,0.005,0.0025$ and $0.0012 \mathrm{mM}$ final concentrations) dissolved in water was mixed with either $100 \mu \mathrm{L}$ of diluted $\mathrm{ABTS}^{+} \bullet$ solution or solvent. The reaction was allowed to proceed for $30 \mathrm{~min}$ at room temperature and was protected from light. The absorbance was recorded at $734 \mathrm{~nm}$ in a transparent 96-well test microplate (Multiskan-EX Thermo Scientific) [51].

The antioxidant activity was calculated as the percentage of the ABTS cationic radicalscavenging activity with the test compound, by the following equation: $\left[1-\left(\mathrm{A}_{1}-\right.\right.$ $\left.\left.\mathrm{A}_{2}\right) /\left(\mathrm{A}_{\mathrm{ABTS}}-\mathrm{A}_{\mathrm{S}}\right)\right] \times 100$, where: $\mathrm{A}_{1}=$ Absorbance of the compound with ABTS; $\mathrm{A}_{2}=$ Absorbance of the compound with solvent, $\mathrm{A}_{\mathrm{ABTS}}=$ Absorbance of ABTS (diluted 1:1 with solvent), $A_{S}=$ Absorbance of DMSO. The reference used for DPPH and ABTS tests was 5-ASA.

\subsection{MPO Enzymatic Activity of Peroxidation}

The enzymatic activity of peroxidation was conducted as has been described previously [52] with modifications. Briefly, hydrogen peroxide (30\%) was mixed with orthodianisidine in phosphate buffer (PBS) $50 \mathrm{mM}, \mathrm{pH} 6.0$ to a final concentration of $0.0050 \%$ $(1632 \mu \mathrm{M})$ and $167 \mu \mathrm{g} / \mathrm{mL}(684 \mu \mathrm{M})$, respectively. In a 96-well plate, $5 \mu \mathrm{L}$ of a stock solution of MPO $(0.0126$ units $/ \mu \mathrm{L})$ were mixed with $5 \mu \mathrm{L}$ of PBS and $10 \mu \mathrm{L}$ of the appropriate concentrated DMSO solution of compounds $\mathbf{2 a - j}, 5$-ASA or 4 -ABAH $(200,100,50,25,12.5,6$ and $3 \mathrm{mM}$ final concentrations per well) and $180 \mu \mathrm{L}$ of the ortho-dianisidine-hydrogen peroxide solution $(616 \mu \mathrm{M} / 1469 \mu \mathrm{M}$ final concentrations per well). Control wells were treated with $10 \mu \mathrm{L}$ of DMSO. The reaction was allowed to react for $30 \mathrm{~min}$ and the absorbance was measured at $460 \mathrm{~nm}$. This assay was performed in triplicate. 


\subsection{MPO Enzymatic Activity of Chlorination}

The enzymatic activity of chlorination was determined by the production of $\mathrm{HOCl}$, using the taurine-chloramine assay, where $\mathrm{HOCl}$ production is detected indirectly by oxidizing 5-thio-2-nitrobenzoic acid (TNB), following a reported procedure [53]. TNB was prepared starting from DTNB, and $20 \mathrm{mg}$ of DTNB $(1.0 \mathrm{mM})$ and $40 \mathrm{mg}$ of $\mathrm{NaBH}_{4}(20 \mathrm{mM})$ were mixed in $50 \mathrm{~mL}$ of $\mathrm{PBS}$ at $\mathrm{pH}=7.4$ and incubated for 30 minutes at room temperature. Then, a dilution was made by taking $430 \mu \mathrm{L}$ of the TNB solution and $4570 \mu \mathrm{L}$ of PBS, whose measured absorbance at $412 \mathrm{~nm}$ of 0.88 units is equivalent to $1.36 \mathrm{mM}$ of TNB. The assay was performed in a 96-well plate, and into each well were placed: 0.126 units of MPO $(10 \mu \mathrm{L}), 53 \mu \mathrm{L}$ of PBS $10 \mathrm{mM}$ at $\mathrm{pH}=7.4$ added to $300 \mathrm{mM} \mathrm{NaCl}, 7 \mu \mathrm{L}$ of $0.15 \mathrm{M}$ taurine (10 mM final concentration). Ten microliters of $2.0 \mathrm{mM}$ DMSO solutions of compounds $2 \mathbf{a}-\mathbf{j}$, 5-ASA or 4-ABAH (100 $\mu \mathrm{M}$ final concentration) and $7 \mu \mathrm{L}$ of $0.1 \%$ hydrogen peroxide (10.3 mM final concentration) were incubated for $10 \mathrm{~min}$. Control wells were treated with $10 \mu \mathrm{L}$ of DMSO instead. The reaction was stopped with $7 \mu \mathrm{L}$ of catalase $4 \mathrm{U} / \mu \mathrm{L}, 10.5 \mu \mathrm{L}$ of TNB and $95.5 \mu \mathrm{L}$ of water. The absorbance was measured at $412 \mathrm{~nm}$ after $10 \mathrm{~min}$.

\subsection{Cell Viability}

The cell line NIH/3T3 was used, following reported procedures [54,55]. The cells were cultured in Dulbecco's modified Eagle medium (DMEM) with phenol red, supplemented with $10 \%$ fetal bovine serum (FBS) and $1 \%$ penicillin/streptomycin. All cells were cultured at $37^{\circ} \mathrm{C}$ in a humidified incubator containing $5 \% \mathrm{CO}_{2}$. The cells were detached using $1 \mathrm{~mL}$ of trypsin $1 \%$ and $4 \mathrm{~mL}$ of PBS-EDTA. Afterwards, the cells were counted, and seeded in 96-well plates at $10 \times 10^{3}$ cells/well. After $24 \mathrm{~h}$, the cells were treated with 12, 25, 50, 100 and $200 \mu \mathrm{M}$ of each compound in a final volume of $100 \mu \mathrm{L}(0.2 \%$ of DMSO), specific wells were dedicated for control cells treated only with medium or medium with DMSO. After $48 \mathrm{~h}$, the medium was removed and replaced by $20 \mu \mathrm{L}$ of PBS containing MTT $(0.5 \mathrm{mg} / \mathrm{mL})$, and the cells were incubated for $3 \mathrm{~h}$, at $37^{\circ} \mathrm{C}$ under $\mathrm{CO}_{2}$. After that, the BS/MTT was discarded, and the formazan crystals produced were solubilized with DMSO (100 $\mu \mathrm{L} /$ well). The optical density was measured at $550 \mathrm{~nm}$ using a microplate reader (Multiskan-EX Thermo Scientific). Results are expressed as percentage of cell viability relative to control. The experiments were performed in triplicate.

\subsection{Docking $M P O$}

Validation of the method was performed with $\mathrm{N}$-acetylglucosamine, reaching an RMSD value of $1.194 \AA$ [48]. Snapshots ( 0,5 and $10 \mathrm{~ns})$ of different conformations of MPO (PDB: 1DNU) were obtained from MD simulations [47]. All ligands were 3D prepared in ChemSketch and optimized using Gaussian 98 software employing the AM1 method. All possible torsions and partial charges were identified and calculated using AutoDock Tools 1.5.6 software. All polar hydrogens were incorporated to the protein along with the Kollman charges for all atoms. All other parameters were maintained at their default values. The protein binding and scanning sites were prepared using a GRID-based method. A box of $126 \AA^{3}$ was employed with a spacing of $0.375 \AA$ centered on the iron atom of the heme group using the conformation at $10 \mathrm{~nm}$. All simulations employed the hybrid Lamarckian genetic algorithm with an initial population of 100 randomly placed individuals and $1 \times 100$ evaluations. Results were analyzed with Discovery Studio Visualizer 19.1 software, to obtain both the binding energy $(\Delta \mathrm{G})$ and the interactions of compounds $(\mathbf{2} \mathbf{a}-\mathbf{2} \mathbf{j})$ with amino acid residues of MPO.

\subsection{Molecular Orbital Calculations}

Calculations were performed as reported [56-58], and a brief summary is described. All molecules and radicals were initially modeled under the semi-empirical method PM3. Geometry optimizations and frequency calculations were performed using DFT calculations at the B3LYP / 6-31 $+G(d, p)$ level of theory for parent molecules $2 \mathbf{a}-\mathbf{j}$, radicals and cation radicals. Vibrational frequencies were scaled by a factor of 0.973 to obtain the scaled 
zero-point energy. The thermal correction of the enthalpy was computed by a single-point calculation with B3LYP/6-31 + G(d,p) level of theory. The total enthalpy at $298.15 \mathrm{~K}$ was calculated as the sum of the thermal correction of the enthalpy and the total electronic energy. The binding dissociation enthalpy values of the $\mathrm{O}-\mathrm{H}$ bond $\left(\mathrm{BDE}_{\mathrm{OH}}\right)$ were calculated according to the formula $\mathrm{BDE}_{\mathrm{OH}}=\mathrm{H}_{\mathrm{R}}+\mathrm{H}_{\mathrm{H}}-\mathrm{H}_{\mathrm{P}}$, where $\mathrm{H}_{\mathrm{R}}$ is the enthalpy of the radical generated by $\mathrm{H}$-abstraction, $\mathrm{H}_{\mathrm{H}}$ is the enthalpy of the $\mathrm{H}$-atom and $\mathrm{H}_{\mathrm{P}}$ is the enthalpy of the corresponding parent compound $\mathbf{2 a}-\mathbf{j}$. The enthalpy value of -0.49764 Hartree was used for the hydrogen atom in all calculations of the BDE. The IP values were obtained according to the equation IP $=E_{R_{+}}-E_{P}$, where $E_{R_{+}}$is the energy of the cation radical, $E_{P}$ is the energy of the corresponding parent compound $\mathbf{2} \mathbf{a}-\mathbf{j}$. All calculations were performed with the Gaussian 09 molecular package [59] in a computer with an unlocked AMD FX processor. All the calculations refer to the gas phase. The Z-matrices, total energy and imaginary frequencies are in the Supplementary Materials.

\subsection{Statistical Analysis}

One-way ANOVA was used for all the assays and a maximum value of $p<0.05$ was considered statistically significant. DPPH, ABTS, MPO enzyme activity of peroxidation and cell viability assays were performed in triplicate whereas the MPO enzyme activity of chlorination assay was performed in duplicate and the results were standardized and expressed as the mean \pm standard error (S.E.). A Tukey post hoc test was used.

\section{Conclusions}

The microwave-assisted synthesis of a family of $(E)$-2-hydroxy- $\alpha$-aminocinnamic acids, analogous to (Z)-2-hydroxycinnamic acids, was successfully achieved in moderate to good yields in a diluted $\mathrm{H}_{2} \mathrm{SO}_{4}$ aqueous solution. The results obtained in the present study have shown that five $(\mathbf{2} \mathbf{f}-\mathbf{j})$ of the ten studied compounds can effectively scavenge DPPH and ABTS free radicals under in vitro conditions, with activities similar to those reported for caffeic acid. The conjugated $\alpha$-aminopropenoic acid skeleton and the substituents on the phenyl ring play an important role in their observed antioxidant properties, with those with a second ED group being the most active. The propensity of compounds $\mathbf{2} \mathbf{a}-\mathbf{j}$ to react through the HAT mechanism rather than the SET mechanism was predicted from $\mathrm{BDE}_{\mathrm{OH}}$, IP and $\Delta \mathrm{E}_{\mathrm{H}-\mathrm{L}}$ theoretical calculations, with compounds $\mathbf{2 a}, \mathbf{2 e}, 2 \mathbf{f}$ and $\mathbf{2 h}$ being the most active by either of the two mechanisms. Furthermore, we have demonstrated that compounds $\mathbf{2 a}, \mathbf{2 e}, \mathbf{2} \mathbf{f}$ and $\mathbf{2 h}$ showed in vitro peroxidation inhibitory activity of MPO with $\mathrm{IC}_{50}$ values comparable to indomethacin and 5-ASA but only the chlorinated derivative $2 \mathrm{c}$ was capable of decreasing the in vitro chlorination activity of the MPO by $40 \%$ while the cytotoxicity of the whole set of compounds was below $15 \%$ at $100-200$ $\mu \mathrm{M}$. Docking calculations allowed for establishing that both amino and carboxylic acid groups of the $\alpha$-aminopropenoic acid arm are required for anchoring to the MPO active site, forming stable complexes comparable to 4-ABAH-MPO and 5-ASA-MPO. To the best of our knowledge, $(E)$-2-hydroxy- $\alpha$-aminocinnamic acids have been synthesized for the first time with a reliable method and their antioxidant properties demonstrated, introducing the possibility to contrast the pharmacological properties between configurational isomers. Finally, the pharmacological properties of these compounds, related to the generation of oxidant species, will be the subject of further research.

Supplementary Materials: The following are available on line at https://www.mdpi.com/article/ 10.3390/ph14060513/s1, Figures S1 and S2: ${ }^{1} \mathrm{H}-\mathrm{NMR}$ spectra showing the effect of the $\mathrm{H}_{2} \mathrm{SO}_{4}$ concentration on the conversion of $1 \mathbf{i}$ to $\mathbf{2} \mathbf{i}$ and $\mathbf{1 a}$ to $\mathbf{2} \mathbf{a}$; Figures S3 and S4: Percentage of DPPH RSA with compounds 2a-j; Figures S5 and S6: Percentage of ABTS RSA with compounds 2a-j; Figure S7: Validation of the molecular docking protocols for MPO with N-Acetyl-D-glucosamine; Figure S8: Percentage inhibition of MPO peroxidation activity with compounds $\mathbf{2 a}, \mathbf{2 e}, \mathbf{2 f}, \mathbf{2 h}$, Indomethacin and 5-ASA; Figures S9-S38: ${ }^{1} \mathrm{H},{ }^{13} \mathrm{C}$ NMR and IR spectra of compounds 2a-j. Table S1: C2-C1-C7-C8 torsion angles of compounds $\mathbf{2} \mathbf{a}-\mathbf{j}$ in their neutral, radical and cation radical forms: Table S2: Cell viability assays; Procedures of acetamidocoumarins synthesis $\mathbf{1 a - j}$. MO calculations at B3LYP/6- 
$31+G(d, p)$, energies, imaginary frequencies and Z-matrix of $\mathbf{2} \mathbf{a}-\mathbf{j}$ in neutral, radical and cation radical forms.

Author Contributions: Methodology, calculations, formal analysis, original draft preparation, A.R.-A.; methodology I.B.-R.; calculations, J.M.S.-Q., E.V.G.-B.; conceptualization, supervision, funding acquisition review and editing, M.C.R.-H.; supervision, review and editing, J.E.M.-W., J.B.G.-V.; methodology, software, J.C.-B.; conceptualization, supervision, funding acquisition, data curation, original draft preparation, review and editing, I.I.P.-M. All authors have read and agreed to the published version of the manuscript.

Funding: This research was funded by CONACYT, grant number 255354 and Secretaría de Investigación y Posgrado del Instituto Politécnico Nacional, grant number 20201274.

Institutional Review Board Statement: Not applicable.

Informed Consent Statement: Not applicable.

Data Availability Statement: The data presented in this study are available on request from the corresponding author.

Conflicts of Interest: The authors declare that they have no known competing financial interest or personal relationships that could have appeared to influence the work reported in this paper. The funders had no role in the design of the study; in the collection, analyses, or interpretation of data; in the writing of the manuscript, or in the decision to publish the results.

\section{References}

1. Aratani, Y. Myeloperoxidase: Its role for host defense, inflammation, and neutrophil function. Arch. Biochem. Biophys. 2018, 640, 47-52. [CrossRef] [PubMed]

2. Nybo, T.; Cai, H.; Chuang, C.Y.; Gamon, L.F.; Rogowska-Wrzesinska, A.; Davies, M.J. Chlorination and oxidation of human plasma fibronectin by myeloperoxidase-derived oxidants, and its consequences for smooth muscle cell function. Redox Biol. 2018, 19, 388-400. [CrossRef] [PubMed]

3. Gamon, L.F.; Dieterich, S.; Ignasiak, M.T.; Schrameyer, V.; Davies, M.J. Iodide modulates protein damage induced by the inflammation-associated heme enzyme myeloperoxidase. Redox Biol. 2020, 28, 101331. [CrossRef] [PubMed]

4. Khalilova, I.S.; Dickerhof, N.; Mocatta, T.J.; Bhagra, C.J.; McClean, D.R.; Obinger, C.; Kettle, A.J. A myeloperoxidase precursor, pro-myeloperoxidase, is present in human plasma and elevated in cardiovascular disease patients. PLoS ONE 2018, 13, e0192952. [CrossRef] [PubMed]

5. Mariani, F.; Roncucci, L. Role of the Vanins-Myeloperoxidase Axis in Colorectal Carcinogenesis. Int. J. Mol. Sci. 2017, 18, 918. [CrossRef] [PubMed]

6. Gellhaar, S.; Sunnemark, D.; Eriksson, H.; Olson, L.; Galter, D. Myeloperoxidase-immunoreactive cells are significantly increased in brain areas affected by neurodegeneration in Parkinson's and Alzheimer's disease. Cell Tissue Res. 2017, 369, 445-454. [CrossRef]

7. Yan, Y.; Ren, F.; Wang, P.; Sun, Y.; Xing, J. Synthesis and evaluation of a prodrug of 5-aminosalicylic acid for the treatment of ulcerative colitis. Iran. J. Basic Med. Sci. 2019, 22, 1452-1461.

8. Forbes, L.V.; Sjögren, T.; Auchère, F.; Jenkins, D.W.; Thong, B.; Laughton, D.; Hemsley, P.; Pairaudeau, G.; Turner, R.; Eriksson, H.; et al. Potent Reversible Inhibition of Myeloperoxidase by Aromatic Hydroxamates. J. Biol. Chem. 2013, 288, 36636-36647. [CrossRef]

9. Cabrera-Pérez, L.C.; Mendieta-Wejebe, J.E.; Hernández, R.M.; Fragoso, M.J.; Salazar, J.R.; Correa-Basurto, J.; Pa-dilla-Martínez, I.I.; Rosales-Hernández, M.C. Novel 5-aminosalicylic derivatives as anti-inflammatories and myeloperoxidase inhibitors evaluated in silico, in vitro and ex vivo. Arab. J. Chem. 2019, 12, 5278-5291. [CrossRef]

10. Van der Veen, B.S.; de Winther, M.P.J.; Heeringa, P. Myeloperoxidase: Molecular Mechanisms of Action and Their Relevance to Human Health and Disease. Antioxid. Redox Signal. 2009, 11, 2899-2937. [CrossRef]

11. Huang, J.; Smith, F.; Panizzi, J.R.; Goodwin, D.C.; Panizzi, P. Inactivation of myeloperoxidase by benzoic acid hydrazide. Arch Biochem. Biophys. 2015, 570, 14-22. [CrossRef] [PubMed]

12. Poljšak, B.; Fink, R. The Protective Role of Antioxidants in the Defence against ROS/RNS-Mediated Environmental Pollution. Oxid. Med. Cell Longev. 2014, 2014, 671539. [CrossRef] [PubMed]

13. Liguori, I.; Russo, G.; Curcio, F.; Bulli, G.; Aran, L.; Della-Morte, D.; Gargiulo, G.; Testa, G.; Cacciatore, F.; Bonaduce, D.; et al. Oxidative stress, aging, and diseases. Clin. Interv. Aging 2018, 13, 757-772. [CrossRef] [PubMed]

14. Peperidou, A.; Pontiki, E.; Hadjipavlou-Litina, D.; Voulgari, E.; Avgoustakis, K. Multifunctional Cinnamic Acid Derivatives. Molecules 2017, 22, 1247. [CrossRef] [PubMed]

15. Wang, Y.; Liang, J.; Luan, G.; Zhang, S.; Zhuoma, Y.; Xie, J.; Zhou, W. Quantitative Analyses of Nine Phenolic Compounds and Their Antioxidant Activities from Thirty-Seven Varieties of Raspberry Grown in the Qinghai-Tibetan Plateau Region. Molecules 2019, 24, 3932. [CrossRef] 
16. Silva, A.T.; Bento, C.M.; Pena, A.C.; Figueiredo, L.M.; Prudêncio, C.; Aguiar, L.; Silva, T.; Ferraz, R.; Gomes, M.S.; Teixeira, C.; et al. Cinnamic Acid Conjugates in the Rescuing and Repurposing of Classical Antimalarial Drugs. Molecules 2019, 25, 66. [CrossRef]

17. Leite-Diniz, L.R.; De Santana-Souza, M.T.; Nascimento-Barboza, J.; Nóbrega-de Almeida, R.; Pergentino de Sousa, D. Antidepressant Potential of Cinnamic Acids: Mechanisms of Action and Perspectives in Drug Development. Molecules 2019, 24, 4469. [CrossRef]

18. Adisakwattana, S. Cinnamic Acid and Its Derivatives: Mechanisms for Prevention and Management of Diabetes and Its Complications. Nutrients 2017, 9, 163. [CrossRef]

19. Teixeira, J.; Gaspar, A.; Garrido, E.M.; Garrido, J.; Borges, F. Hydroxycinnamic Acid Antioxidants: An Electrochemical Overview. BioMed Res. Int. 2013, 2013, 1-11. [CrossRef]

20. Vega, M.R.G.; De Carvalho, M.G.; Vieira, I.J.C.; Filho, R.B. Chemical constituents from the Paraguayan medicinal plant, Eupatorium macrocephalum Less. J. Nat. Med. 2007, 62, 122-123. [CrossRef]

21. Wu, J.; Zhang, S.; Long, L. Two (2)-4-hydroxycinnamic acid glycosides and their application. China's Patent CN 1515580 A 20040728, 28 July 2004.

22. Yen, G.-C.; Chen, Y.-L.; Sun, F.-M.; Chiang, Y.-L.; Lu, S.-H.; Weng, C.-J. A comparative study on the effectiveness of cis- and transform of cinnamic acid treatments for inhibiting invasive activity of human lung adenocarcinoma cells. Eur. J. Pharm. Sci. 2011, 44, 281-287. [CrossRef]

23. Salum, M.L.; Balsells, R.E. High Purity cis-Cinnamic Acid Preparation for Studying Physiological Role of trans-Cinnamic and cis-Cinnamic Acids in Higher Plants. Environ. Control. Biol. 2013, 51, 1-10. [CrossRef]

24. Horaguchi, T.; Nobuyuki, H.; Tanemura, K.; Suzuki, T. Photocyclization Reactions. Part 8. Synthesis of 2-quinolone, quinoline and coumarin derivatives using trans-cis isomerization by photoreaction. J. Heterocyclic Chem. 2002, 39, 61-67. [CrossRef]

25. Anastas, P.; Eghbali, N. Green Chemistry: Principles and Practice. Chem. Soc. Rev. 2009, 39, 301-312. [CrossRef] [PubMed]

26. Ondruschka, B.; Bonrath, W.; Stuerga, D. Development and Design of Reactors in Microwave-Assisted Chemistry. In Microwaves in Organic Synthesis; Wiley: Hoboken, NJ, USA, 2013; Volume 1, pp. 57-103.

27. Bogart, J.W.; Bowers, A.A. Dehydroamino acids: Chemical multi-tools for late-stage diversification. Org. Biomol. Chem. 2019, 17, 3653-3669. [CrossRef] [PubMed]

28. Veloso, S.R.; Jervis, P.J.; Silva, J.F.; Hilliou, L.; Moura, C.; Pereira, D.M.; Coutinho, P.J.; Martins, J.; Castanheira, E.M.; Ferreira, P.M. Supramolecular ultra-short carboxybenzyl-protected dehydropeptide-based hydrogels for drug delivery. Mater. Sci. Eng. C 2021, 122, 111869. [CrossRef] [PubMed]

29. Das, D.K.; Sarkar, S.; Khan, M.; Belal, M.; Khan, A.T. A mild and efficient method for large scale synthesis of 3-aminocoumarins and its further application for the preparation of 4-bromo-3-aminocoumarins. Tetrahedron Lett. 2014, 55, 4869-4874. [CrossRef]

30. Lončarić, M.; Gašo-Sokač, D.; Jokić, S.; Molnar, M. Recent Advances in the Synthesis of Coumarin Derivatives from Dif-ferent Starting Materials. Biomolecules 2020, 10, 151. [CrossRef]

31. Kudale, A.A.; Kendall, J.; Warford, C.C.; Wilkins, N.D.; Bodwell, G.J. Hydrolysis-free synthesis of 3-aminocoumarins. Tetrahedron Lett. 2007, 48, 5077-5080. [CrossRef]

32. Martínez-Martínez, F.J.; Padilla-Martínez, I.I.; Trujillo-Ferrara, J. ${ }^{1} \mathrm{H}$ and ${ }^{13} \mathrm{C}$ NMR assignments of 2-oxo-2H-1-benzopyran-3-acyl and -3-amide derivatives. Magn. Reson. Chem. 2001, 39, 765-767. [CrossRef]

33. Borges, R.S.; Castle, S.L. The antioxidant properties of salicylate derivatives: A possible new mechanism of anti-inflammatory activity. Bioorg. Med. Chem. Lett. 2015, 25, 4808-4811. [CrossRef] [PubMed]

34. Aldawsari, F.S.; Aguiar, R.P.; Wiirzler, L.A.M.; Aguayo-Ortiz, R.; Aljuhani, N.; Cuman, R.K.N.; Medina-Franco, J.L.; Siraki, A.G.; Velázquez-Martínez, C.A. Anti-inflammatory and antioxidant properties of a novel resveratrol-salicylate hybrid analogue. Bioorg. Med. Chem. Lett. 2016, 26, 1411-1415.

35. Gülçin, İ. Antioxidant activity of caffeic acid (3,4-dihydroxycinnamic acid). Toxicology 2006, 17, 213-220. [CrossRef] [PubMed]

36. Gulcin, İ. Antioxidants and antioxidant methods: An updated overview. Arch. Toxicol. 2020, 94, 651-715. [CrossRef] [PubMed]

37. Mathew, S.; Abraham, T.E.; Zakaria, Z.A. Reactivity of phenolic compounds towards free radicals under in vitro conditions. J. Food Sci. Technol. 2015, 52, 5790-5798. [CrossRef] [PubMed]

38. Bolton, J.L.; Dunlap, T. Formation and Biological Targets of Quinones: Cytotoxic versus Cytoprotective Effects. Chem. Res. Toxicol. 2017, 30, 13-37. [CrossRef]

39. Apak, R.; Özyürek, M.; Güçlü, K.; Çapanoğlu, E. Antioxidant Activity/Capacity Measurement. 1. Classification, Physicochemical Principles, Mechanisms, and Electron Transfer (ET)-Based Assays. J. Agric. Food Chem. 2016, 64, 997-1027. [CrossRef]

40. Giacomelli, C.; Miranda, F.D.S.; Gonçalves, N.S.; Spinelli, A. Antioxidant activity of phenolic and related compounds: A density functional theory study on the O-H bond dissociation enthalpy. Redox Rep. 2004, 9, 263-269. [CrossRef] [PubMed]

41. Nenadis, N.; Wang, L.-F.; Tsimidou, M.; Zhang, H.-Y. Estimation of Scavenging Activity of Phenolic Compounds Using the ABTS•+Assay. J. Agric. Food Chem. 2004, 52, 4669-4674. [CrossRef]

42. Woldu, A.S.; Mai, J. Computation of the bond dissociation enthalpies and free energies of hydroxylic antioxidants using the ab initio Hartree-Fock method. Redox Rep. 2012, 17, 252-274. [CrossRef]

43. Warren, J.J.; Tronic, T.A.; Mayer, J.M. Thermochemistry of Proton-Coupled Electron Transfer Reagents and its Implications. Chem. Rev. 2010, 110, 6961-7001. [CrossRef] [PubMed]

44. León-Carmona, J.R.; Alvarez-Idaboy, J.R.; Galano, A. On the peroxyl scavenging activity of hydroxycinnamic acid derivatives: Mechanisms, kinetics, and importance of the acid-base equilibrium. Phys. Chem. Chem. Phys. 2012, 14, 12534-12543. [CrossRef] 
45. Szelag, M.; Urbaniak, A.; Bluyssen, H.A. A theoretical antioxidant pharmacophore for natural hydroxycinnamic acids. Open Chem. 2015, 13, 17-31. [CrossRef]

46. Zouchoune, B. How the ascorbic acid and hesperidin do improve the biological activities of the cinnamon: Theoretical investigation. Struct. Chem. 2020, 31, 2333-2340. [CrossRef] [PubMed]

47. Ramírez-Durán, L.A.; Rosales-Hernández, M.C.; Hernández-Rodríguez, M.; Mendieta-Wejebe, J.E.; Trujillo-Ferrara, J.; CorreaBasurto, J. Mapping myeloperoxidase to identify its promiscuity properties using docking and molecular dynamics simulations. Curr. Pharm. Des. 2013, 19, 2204-2215. [CrossRef] [PubMed]

48. Costa, J.D.S.; Ramos, R.D.S.; Costa, K.D.S.L.; Brasil, D.D.S.B.; Silva, C.H.T.D.P.D.; Ferreira, E.F.B.; Borges, R.D.S.; Campos, J.M.; Macêdo, W.J.D.C.; Dos Santos, C.B.R. An in Silico Study of the Antioxidant Ability for Two Caffeine Analogs Using Molecular Docking and Quantum Chemical Methods. Molecules 2018, 23, 2801. [CrossRef]

49. Shacter, E.; Lopez, R.L.; Pati, S. Inhibition of the myeloperoxidase- $\mathrm{H}_{2} \mathrm{O}_{2}-\mathrm{Cl}-$ system of neutrophils by indomethacin and other non-steroidal anti-inflammatory drugs. Biochem. Pharmacol. 1991, 41, 975-984. [CrossRef]

50. Duclos, F.; Abell, L.M.; Harden, D.G.; Pike, K.; Nowak, K.; Locke, G.A.; Duke, G.J.; Liu, X.; Fernando, G.; Shaw, S.A.; et al. Triazolopyrimidines identified as reversible myeloperoxidase inhibitors. MedChemComm 2017, 8, 2093-2099. [CrossRef] [PubMed]

51. Kotora, P.; Šeršeň, F.; Filo, J.; Loos, D.; Gregáň, J.; Gregáň, F. The Scavenging of DPPH, Galvinoxyl and ABTS Radicals by Imine Analogs of Resveratrol. Molecules 2016, 21, 127. [CrossRef]

52. Bradley, P.; Christensen, R.; Rothstein, G. Cellular and extracelular myeloperoxidase in pyogenic inflammation. Blood 1982, 60, 618-622. [CrossRef]

53. Kettle, A.J.; A Gedye, C.; Hampton, M.B.; Winterbourn, C.C. Inhibition of myeloperoxidase by benzoic acid hydrazides. Biochem. J. 1995, 308, 559-563. [CrossRef]

54. Mosmann, T. Rapid colorimetric assay for cellular growth and survival: Application to proliferation and cytotoxicity assays. J. Immunol. Methods 1983, 65, 55-63. [CrossRef]

55. Denizot, F.; Lang, R. Rapid colorimetric assay for cell growth and survival. Modifications to the tetrazolium dye procedure giving improved sensitivity and reliability. J. Immunol. Methods 1986, 89, 271-277. [CrossRef]

56. DiLabio, G.; Pratt, D.; Wright, J. Theoretical calculation of gas-phase ionization potentials for mono- and polysubstituted benzenes. Chem. Phys. Lett. 1999, 311, 215-220. [CrossRef]

57. Wright, J.S.; Johnson, A.E.R.; DiLabio, G.A. Predicting the Activity of Phenolic Antioxidants: Theoretical Method, Analysis of Substituent Effects, and Application to Major Families of Antioxidants. J. Am. Chem. Soc. 2001, 123, 1173-1183. [CrossRef] [PubMed]

58. Vakarelska-Popovska, M.H.; Velkov, Z. Monohydroxy flavones. Part IV: Ehthalpies of different ways of O-H bond dissociation. Comput. Theor. Chem. 2016, 1077, 87-91. [CrossRef]

59. Frisch, M.J.; Trucks, G.W.; Schlegel, H.B.; Scuseria, G.E.; Robb, M.A.; Cheeseman, J.R.; Scalmani, G.; Barone, V.; Mennucci, B.; Petersson, G.A. Gaussian 09, Revision A.02; Gaussian, Inc.: Wallingford, CT, USA, 2009. 